\title{
THE ROLE OF HISTORY AND ARCHAEOLOGY IN THE ASPECTS OF THE DEVELOPMENT OF THE MODERN WORLD
}

\section{Collective monograph}

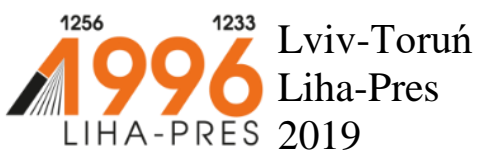




\section{Reviewers:}

Prof. nadzw., dr hab. Stanistaw Kunikowski, Rektor of Cuiavian University in Wloclawek (Republic of Poland);

Prof. dr hab. Joanna Marszalek-Kawa, Uniwersytet Mikotaja Kopernika w Toruniu / Nicolaus Copernicus University (Republic of Poland).

The role of history and archaeology in the aspects of the development of the modern world : collective monograph / Yu. Dobrolyubska, O. Likhachova, S. Oriekhova, O. Prysiazhniuk. Lviv-Torun : Liha-Pres, 2019. - 96 p.

ISBN 978-966-397-169-8

Liha-Pres is an international publishing house which belongs to the category "C" according to the classification of Research School for Socio-Economic and Natural Sciences of the Environment (SENSE) [isn: 3943, 1705, 1704, 1703, 1702, 1701; prefixMetCode: 978966397]. Official website www.sense.nl. 


\section{CONTENTS}

EXPERIENCE OF CREATING A PROSOPOGRAPHIC

PORTRAIT OF PROFESSOR BORIS ALEKSEEVICH

SHUSTOV (1880-1945)

Yuliia Dobrolyubska .................................................................................................

PERCEPTIONS OF THE PROBLEMS OF THE JEWISH POPULATION IN ODESSA JOURNALISM

IN THE 50-60 OF 19TH CENTURY

Olga Likhachova

EUROPEAN PRACTICES OF ISSUANCE OF STAMPS:

HISTORICAL AND CULTURAL ASPECTS

Svetlana Oriekhova

MUSEOLOGY AND MONUMENT PROTECTION

IN THE DISCOURSE OF FRENCH NATIONAL IDENTITY

Oleksii Prysiazhniuk .68 

DOI https://doi.org/10.36059/978-966-397-169-8/1-23

\section{EXPERIENCE OF CREATING A PROSOPOGRAPHIC PORTRAIT OF PROFESSOR BORIS ALEKSEEVICH SHUSTOV (1880-1945)}

\section{Yuliia Dobrolyubska}

\section{INTRODUCTION}

At the beginning of the 21st century, the personification of history, which sets the basis of events and phenomena of the past person with its extraordinary intellectual and organizational skills, civic position, endowments and concrete Actions. The strong interest of the famous person, observed in recent decades, encourages the researcher not only to write her biography, to list facts and events of life and activity, but also to deepen her personal essence, which often explains the causes and Consequences of biographic facts. That is, the personification of the past, as an actual task of modern historical studios, involves the reproduction of the gallery of famous figures not in the traditional coverage of the usual biography, but in a deeper study of personal and individual content of a particular person or groups of people linked by generic, professional or other relationships.

This interest in a person in history requires from modern researchers not only writing biographies, enumeration and refinement of individual facts, dates, but also in-depth study of human personality, throughout the versatility of her socio-psychological and individual Rice. In the context of mass desecration of archival documents and active introduction to the scientific circulation of new sources of historians and source studies, it becomes available valuable material of impregnating nature. It allows you to create live portraits of famous people, reproduce their images in a combination of positive and negative sides biography, not enclosed in a static framework of dry biography.

The purpose of this article is to create an impregnating portrait of arborist Boris Alekseevich Shustov because of the most characteristic aspects of his biography. 


\section{The personal destiny of the arborist in the context of social change}

The description of the history of the persecution of foresters of Ukraine in 1930 (case of the All-Ukrainian Forest Management or VUPL) was reflected in the books of P. G. Vakuluk "The Case of VUPL", "Rehabilitated by History", "Essays on Forest History Ukraine", "Foresters are victims of the totalitarian system"3, "Foresters are the chief forest manager", "Reforestation and deforestation in Ukraine" . Shustov's accusations of counter-revolutionary pestilence are remembered in the book "The First Figures of Ukrainian Forestry" by O. I. Furdychko and V. D. Bondarenko ${ }^{6}$. The materials of the investigation on the case of the VUPL, including the accusations of Professor B. A. Shustov, are briefly described in the book by V. E. Boreiko "White Spots of Nature Conservation"7.

Interesting material for understanding the relationship of the totalitarian regime with the Ukrainian intelligentsia is provided by V. G. Kasyanov's research "Ukrainian Intelligence of the 1920s 1930s: A Social Portrait and a Historical Destiny"”.

Overall, the analysis of the historiography of the forestry shows numerous gaps in the coverage of the period in the history of the industry. There are no studies on the activity in the specified field by Professor B. A. Shustov.

${ }^{1}$ Vakuljuk P. G. (1994) Sprava VUPLu [The case of VUPL]. Kiev: [b. v.].

${ }^{2}$ Vakuljuk P. G. (1998) Reabilitovani istorijeju [Rehabilitated by History]. Kiev: [b. v.].

${ }^{3}$ Vakuljuk P. G. (2004) Lisivnyky - zhertvy totalitarnoji systemy [Foresters are victims of the totalitarian system]. Kiev: Ukrcentrkadrlis.

${ }^{4}$ Vakuljuk P. G. (2005) Lisnychyj - gholovnyj ghospodar lisu [Foresters are the chief forest manager]. Kiev: Ukrcentrokadrlis.

5 Vakuljuk P. G. (2006) Lisovidnovlennja ta lisorozvedennja v Ukrajini [Reforestation and deforestation in Ukraine]. Kharkov: Prapor.

6 Furdychko O. I., Bondarenko V. D. (2000) Pershopostati ukrajinsjkogho lisivnyctva. Narysy do lisovoji istoriji [The First Figures of Ukrainian Forestry. Essays on forest history]. Lviv: Bibljos.

7 Boreyko V.E. (2003) Belye pyatna prirodookhrany [White spots of Nature Conservation]. Kiev: Logos.

${ }^{8}$ Kasjjanov V. G. (1992) Ukrajinsjka intelighencija 1920-kh - 1930-kh rokiv: socialjnyj portret ta istorychna dolja [Ukrainian Intelligence of the 1920s - 1930s: A Social Portrait and a Historical Destiny]. K.: Ghlobus. 
Mostly unpublished sources were used to write this study, which formed the basis of our work. By their specific features, these sources can be divided into two groups: unpublished materials kept in state institutions and unpublished materials of the family archive of the author, the greatgranddaughter of Boris Shustov. From the documents of the family archive, which were miraculously preserved by the grandmother of the author of this work, Marina Borisovna Shustova, miraculously against the war, evacuation and many relocations of the family, were used: diploma of the New Alexandrian Imperial Forest Institute 1907, passport 1909, passport 1919-1937, employment record 1937-1945, autobiography 1942, order on the assignment of the academic title of professor in 1942, order for the transfer of the family to the village of Lubyan Tatar ASSR 1942, autobiography 1944, death certificate B. A. Shustov 1945.

A valuable source of information on the history of Ukrainian forestry and forestry during the first post-revolutionary decades, as well as the state of forestry in the late 1920s. became the documents of the Branch State Archives of the Security Service of Ukraine, which holds the three-volume case No. 68461 on allegations of counterrevolutionary activity by a group of leading Ukrainian forestry experts (the case of VUPL). Among the significant texts of the testimony of the investigating professors, numerous details of biographies of forestry workers, including Boris Shustov, are also revealed ${ }^{9}$.

Boris Shustov was born on October 22 (9), 1880 in the town of Sedniv, Chernihiv province, to the family of village teacher Alexei Shustov and his wife, Agathia Petrovna. Consistory in the metric book of registration of act records of the birth of St. George Church in the town of Sedniv of Chernihiv county of Chernihiv province for 1880 is act record No. $34^{10}$.

${ }^{9}$ Delo VUPL. Otraslevoy gosudarstvennyy arkhiv Sluzhby bezopasnosti Ukrainy (OGA SB Ukrainy) [Case of VUPL. Branch State Archive of the Security Service of Ukraine (BSA SS of Ukraine)]. D. 68461. vol. 1-3. (unpublished); Protokol sudebnogo zasedaniya ot $14.06 .30 \mathrm{~g}$. [The record of the court hearing of June 14, 30]. OGA SB Ukrainy [BSA SS of Ukraine]. D. 68461. vol. 2. p. 630. (unpublished)

${ }^{10}$ Arkhivnyj fond Chernighivsjkoji dukhovnoji konsystoriji f. 679, op. 10, spr. 317, ark. $440 z v$. [Archive Fund of the Chernigiv Spiritual Consistory. F. 679. Op. 10. Sp. 317, arch. $440 \mathrm{zv}$ ]. (unpublished) 
In 1902 he graduated from the Uman School of Agriculture and Horticulture, and in 1907 - St. Petersburg (Novo-Alexandria) Forest Institute with the title of scholar of the 1st class. As the best alumnus B. Shustov was enrolled for 2 years with a scholarship of the highest salary from Professor M. M. Orlov. In 1908-1916 he was an assistant at the Department of Forest Management and Forest Taxation, managed by M. M. Orlov. With the outbreak of World War I, by the order of the military command in 1914, the institute was evacuated to Kharkov. Already in November 1914, classes began in Kharkov, which were held both in the auditoriums of the University, and of the Technological and Veterinary Institutes. In 1917, the Academic Council of the New Alexandria Institute of Agriculture and Forestry, on the recommendation of M. M. Orlov, elected B. A. Shustov Professor of the Department of Forest Taxation. Released from military service, Shustov left the Forest Institute in Petrograd and moved to Kharkov.

In 1919, during the reign of the Denikinists in Kharkov, in search of additional earnings, B. A. Shustov, together with his colleagues, Alexander Kolesnikov, Ivan Kovalenko and Boris Padalko, organized a private office on Rybnaya Street in Ribnaya Street. Bureau has undertaken work on forestry plans and forest evaluation for the needs of their owners and peasant communities ${ }^{11}$.

On March 21, 1921, the Novo-Alexandria Institute of Agriculture and Forestry was named Kharkov Agricultural Institute. The Institute was classified as a particularly important institution, which provided for its urgent full provision of everything necessary. In the same year, the Institute started new structural units - faculties: agronomic, amelioration and forestry. At the general meeting of faculty and students of the Faculty of Forestry, the first dean elected the most experienced professor, Alexander Marchenko. After his transition to the post of director of the All-Ukrainian Forest Management (VUPL), Professor Boris Shustov was elected the second dean in the fall of 1922.

11 Triputina N. P. (2011) Professor A. I. Kolesnikov: stranitsy zhizni i deyatel'nosti [Professor A. I. Kolesnikov: pages of life and activity]. Kharkov: KhNAGKh. 
Since 1922 new departments have been created at the Faculty of Forestry: Dendrology (Head - Professor V. M. Andriyev), Forest Cultures (Head - Professors A. P. Tolsky, I. O. Yakhontov), Forest Taxation (Head - Professor B. A. Shustov), forest reclamation (heads professors M. M. Stepanov, V. Y. Gursky), state forestry and forestry statistics (head A. Kolesnikov). The Department of Forestry has been headed by the renowned professor G. M. Vysotsky since 1925. In 1927, they also organized a research department of forestry in four sections: forestry, dendrology, forest crops and forest reclamation. Professor G. M. Vysotsky was also the head of this department, and the sections were headed by Professors V. M. Andriyev, I. O. Yakhontov, V. Y. Gursky. In December 1929, the Ukrainian Research Institute of Forestry and Agroforestry was organized on the basis of the Research Department of Forestry.

Until 1930, B. A. Shustov was Professor and Head of the Department of Forest Taxation of the Kharkov Agricultural Institute, including 3 years (from 1922 to 1925) - Dean of the Faculty of Forestry. He was also the Deputy Chief of the All-Ukrainian Forest Directorate (VUPL).

On January 20, 1930, Professor B..A. Shustov was arrested and convicted of anti-Soviet counter-revolutionary activity.

The materials of the archival investigative case do not contain information about the place of serving the sentences of the convicted persons and the actual term of their imprisonment. Kyiv researcher P. G. Vakuluk found unofficial information that the sentenced persons in the case owed to the great enthusiast of the forestry business to the Chairman of the National People's Commissar V. Y. Chubar ${ }^{12}$. Professor Shustov's autobiography from 1942, which is preserved in the family archive, states: "From the second half of 1930 and the first half of 1931, he served sentences in the general detention facilities of the city of Kharkov while conducting research". But in another autobiography, which according to a handwritten note

${ }^{12}$ Vakuljuk P. G. (2000) Narysy z istoriji lisiv Ukrajiny [Essays on Forest History Ukraine]. Fastiv: Polifast. p. 287. 
on his return to Bryansk can be dated in the autumn of 1944, there is no mention of arrest and court.

Soviet authorities nationalized the forests of Ukraine. To develop strategy and tactics of managing this complex and extremely neglected economy, to prepare highly qualified specialists in this matter, the newly created departments of Kharkov Agricultural Institute were called $^{13}$.

In the spring of 1920, the All-Ukrainian Forest Management (VUPL) was established in Kharkov under the People's Commissariat of Land Affairs of the Ukrainian SSR.

With the strengthening of the totalitarian system in the country, persecution against domestic specialists of the old school increased. In early 1928, Stalin put forward the thesis of further exacerbation and class struggle in the process of building socialism. The Shakhtin case, the Prom-Party process, and mass political repression against employees of Kharkov agricultural universities were inspired ${ }^{14}$. The target of one of the lawsuits to combat "counter-revolutionary pest" was the heads of the All-Ukrainian Forest Management (VUPL). In the autumn of 1929, Ukrainian foresters were one by one behind the bars: Valerian Gursky, Ivan Kovalenko, Boris Padalko, Alexander Marchenko, Boris Shustov.

The so-called "witnesses" - F. Golovchenko, P. Vorobyov, A. Tsirkul, E. Sadovsky, A. Nikitenko, S. Vasilyev - helped a lot.

F. Golovchenko told the Chekists that the "enemies" did not publish in the magazine "Ukrainian Arborist" his articles, which called for a socialist reconstruction of forestry. However, the young "red arborist" Pavel Vorobyov helped the investigators especially with great care. As a student of the Faculty of Forestry of Kharkov Agricultural Institute, he was offended by Professor Shustov when he rejected his project of felling in the Gomolshansky Forest Cottage. And now, taking advantage of the opportunity, he kept billing. As the famous "friend of the French people"

${ }^{13}$ Pyatnitskiy S. S. (1966) Istoricheskiy ocherk fakul'teta lesovodstva [History of the Faculty of Forestry]. 150 let Khar'kovskomu ordena Trudovogo krasnogo znameni sel'skokhozyaystvennomu institutu im. V. V. Dokuchaeva (1816-1966) [150 years of the Kharkov Order of the Red Banner of Labor Agricultural Institute. V. V. Dokuchaev (1816-1966)]. p. 94.

${ }^{14}$ Kasjjanov V. G. (1992) Ukrajinsjka intelighencija. Pp. 92-93. 
Jean-Paul-Marat, until the revolution, unknown to any physician and unsuccessful chemist, overwhelmed the head of the French Academy of Lavoisier with his work on pathology. With his directness, Lavoisier informed Marat of his negative assessment of these works. In 1789, Marat became one of the most brutal leaders of the revolution and remembered ancient dinners. He persistently demanded in the Convention executions for Lavoisier - "the redeemer and the enemy of the people". The great chemist was on the guillotine. Undoubtedly, Vorobyev's "red arborist" was far away from Marat, but he fulfilled his black duty as a prosecution witness to the end, providing the investigation with the desired evidence of the suspected counter-revolutionary activity ${ }^{15}$.

As a result of several months of heavy interrogation, the prisoners were brought to self-denial (a legal term). They have almost all admitted the accusations made against them.

At a court hearing on June 14, 1930, Professor B. A. Shustov was found guilty of "jointly with a group of other employees of VUPL counter-revolutionary forestry specialists, mainly old figures of the forest department, aimed at disrupting the forest by directing capitalist forms, the perversion of practical measures in the forestry sector, a number of harmful actions in different areas of forestry, and the weakening of the economic power of the USSR" ${ }^{\text {"16. }}$.

The opinion of the Kyiv City Prosecutor's Office of December 20, 1991 stated: "The sentence is based on the self-refutation and condemnation of the sentenced employees of the Marchenko, Shustov, Gursky, Kovalenko and Padalka Forestry, and there is no objectively reliable evidence in the case. Testimony of witnesses Sadovsky, Vorobyov, Golovchenko, etc. do not contain information on the counter-revolutionary activities of the prisoners ${ }^{17}$.

15 Boreyko V. E. (2003) Belye pyatna prirodookhrany. p. 14.

${ }^{16}$ Obvinitel'noe zaklyuchenie po "Delu VUPL" [Indictment on VUPL Case]. OGA SB Ukrainy [BSA SS of Ukraine]. D. 68461. Vol. 2. Pp. 186-187. (unpublished)

17 Zaklyuchenie Prokuratury g. Kieva ot 20.12.1990 g. v otnoshenii Kolesnikova A. I. po materialam ugolovnogo dela [The conclusion of the Prosecutor's Office in Kiev dated 12/20/1990 in relation to A. Kolesnikov based on the materials of the criminal case]. OGA SB Ukrainy [BSA SS of Ukraine]. D. 68461. Vol. 2. P. 23. (unpublished) 
Although the investigation is not over yet, the forestry community is already raising its angry voice against the "pests". February 27, 1930, the board of the institute from angered students of the first year of the faculty of the organization of agriculture, land reclamation and forestry faculty received a characteristic requirement at that time "to release the scoundrel Levakovsky from the faculty of the institute" for the fact that he voted against the resolution, "which exposed the pests of social construction - former professors of lesfak" ".

The author of the devastating article in the fourth issue of Ukrainian Arborist in 1930, M. I. Romanovsky stated: "This counterrevolutionary group in forestry, using its position in responsible positions in the forestry, set itself the task of preserving the landlords first of all" L. Dashkevich in the article "For the proletarian cadres" in the same "Ukrainian Arborist" stated: "The matter of training forestry personnel is in the hands of a class alien to us professors" ${ }^{20}$. A resolution of the All-Ukrainian Union of Agricultural and Forestry Workers, published in the same journal, called for "the harshest punishment for a group of pests-specialists in agriculture and forestry" ${ }^{21}$. However, attacks on the forest fossils did not save the last surviving professional forest journal of Ukraine at the time: its management was accused of pestering a pest group, and the 1930s became the last year of issue of this print body. The decision of the future court did not cause any doubt.

18 Protokol obshchego sobraniya studentov KhSKhI [Protocol of the general meeting of students of the KhSKhI]. Derzhavnyj arkhiv Kharjkivsjkoji oblasti [The State Archive of Kharkiv Oblast]. f. R-1148. op. 7. d. 37. 1. 52. (unpublished)

${ }^{19}$ Romanivsjkyj I. (1930) Na borotjbu z kontr-revoljucijnym shkidnyctvom [To combat counter-revolutionary wreckage]. Ukrajinsjkyj lisovod [Ukrainian arborist]. № 4. P. 1 .

${ }^{20}$ Dashkevych L. (1930) Za proletarsjki kadry [For proletarian shots]. Ukrajinsjkyj lisovod [Ukrainian arborist]. № 10/12. P. 8.

21 Najsuvorishoji kary ghrupi shkidnykiv-specialistiv v siljsjkomu ta lisovomu ghospodarstvi Ukrajiny: postanova prezydiji VUKu SGhLR pro shkidnycjku orghanizacijeju v siljsjkomu ta lisovomu ghospodarstvi Ukrajiny (1930) [The harshest punishment for a group of pests-specialists in agriculture and forestry of Ukraine: the decision of the Presidium of VUK of the SGLR on a pest organization in agriculture and forestry of Ukraine]. Ukrajinsjkyj lisovod [Ukrainian arborist]. № 4. Pp. 5-6. 
In the late 1920's, beginning with the Soviet Union's industrialization, the need for business wood increased not only for domestic use but also for the purpose of obtaining currency to cover the cost of importing foreign equipment. Stalinist policy of "socialist assault" required the formation of organs of the forest this type of economy is of the economic-production type instead of the existing management one. The VUPL protected the forests from increased felling, determined logs for each year only in accordance with estimated estimates, and fined the industry for excess felling and failure to comply with clearing rules. On the basis of the resolution of the Ukrainian Economic Meeting of July 23, 1923, the only logger in Ukraine was approved by the All-Ukrainian Forest Management, which was to supply the already developed forest to industrial organizations $\mathrm{s}^{22}$. To eliminate foresters from logging, it was necessary to organize forest management on a "new basis".

On July 12, 1929, the Labor and Defense Council of the RSFSR adopted a decree "On the reorganization of the forestry and forest industry". Its preamble testified that the restructuring was carried out "with the aim of developing the timber industry, more fully meeting the needs of timber, maximizing forest exports, reducing the cost of production of timber industry and increasing the size of forestry profits". August 27, 1929 issued a resolution of the USSR Labor and Defense Council "On the prospective plan for the development of forestry and forest industry of the USSR for the five years 1928/1929 - 1932/1933". With its adoption, "Ukrainian forestry lost its independence and had to put to the fore the forest management task on the basis of lowered timber needs calculations" ${ }^{\prime 23}$.

On November 13, 1929, in accordance with the decision to reform the forest industry, instead of the abolished HPP in Ukraine, the management of Ukrderzhles was formed. Head of the Central Department of Forests of the People's Commissar of the USSR M. G. Zdoryk cynically stated: "As long as we need a forest, we will cut it down to the size of our need,

${ }^{22}$ Ivanycjkyj B. G. (1936) Lisy i lisove ghospodarstvo na Ukrajini [Forests and forestry in Ukraine]. T. 2. Varshava. P. 79.

${ }^{23}$ Ivanycjkyj B. G. (1936) Lisy i lisove ghospodarstvo na Ukrajini. P. 80. 


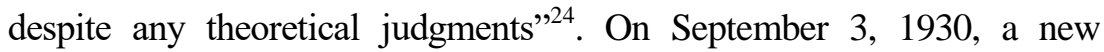
resolution was issued, "On the Organization of the Forest Industry and Forestry", by which Moscow selected forest funds of the Union republics solely on its own ${ }^{25}$.

There was a heated debate among foresters about the principles of forest management. The fundamental principles of sustainability, unacceptability of exhaustion and continuity of use of the forest, developed by the classic of forest science G. F. Morozov and laid down in the forest management instruction of the RSFSR in 1926 by his colleague M. M. Orlov were severely criticized. Based on this instruction, a similar instruction was drawn up in 1927 for Ukraine. This bacchanalia was called "the ideological struggle on the forest front". The result of this "discussion" was, in fact, the defeat of forest science, the arrests and repression of the entire leadership.

In Ukraine, during this period, forestry was merged with the logging bodies, and the state farms were formed, called to "carry out all production processes for logging, raising the productivity of forest stands and improving their quality, logging, primary processing and processing of wood" ${ }^{\prime 26}$. It was exactly what competent experts warned in 1923 - the interests of the forestry were fully subordinated to the interests of the forest industry. This, in particular, was reflected in the list of scientific topics on which the Ukrainian Research Institute of Forestry and Agroforestry worked during the first years of existence ${ }^{27}$. In connection with the reorganization during which the All-Ukrainian Forest Management was abolished, trade unions of forest workers and woodworkers were also united. In the autumn of 1930, the 1st United All-Ukrainian Congress of the Union of Forestry Workers and Forestry Workers (according to the terminology of the time), which outlined measures to "transfer the production experience of woodworking

${ }^{24}$ Red'ko G. I. (2002) Istoriya lesnogo khozyaystva v Rossii [History of forestry in Russia]. Moscow: MGUL. P. 393.

${ }^{25}$ Ivanycjkyj B. G. (1936) Lisy i lisove ghospodarstvo na Ukrajini. P. 81.

${ }^{26}$ Ghuba A. (1929) Na novi rejky [On new rails]. Ukrajinsjkyj lisovod [Ukrainian arborist]. № 12. P. 28.

27 Tkach V.P., Mjeshkova V. L. (ed.) (2005) UkrNDILGhA [UkrNDILGhA]. Kharkov: UkrNDILGhA. P. 12-14, 17. 
enterprises to the work of forestry". The congress also supported the decision of a special commission to clean the Central Committee ${ }^{28}$.

At the same time, a campaign on moral harassment, administrative and judicial prosecution of forestry experts and leading foresters of Ukraine was launched.

Lacking objective information about the harmful activities of the detainees, the GPU began to accumulate information during mass interrogations of forestry workers ${ }^{29}$. The technology of gathering accusatory evidence was mainly that in endless "interviews" investigators, through moral and physical pressure, forced the suspects and witnesses (because who and what the bench would have to determine in court) tell their own biographies in the smallest detail, describe all events occurring in the national forestry for the last $15-20$ years.

It was also necessary to characterize the activities of as many colleagues as possible. Then began the intensified inflating of professional differences between the individual defendants in the case, and the right was recognized by one whose position more fully met the needs of "socialist construction". All other options were considered hostile and harmful. For example, the witness the arrest of V. Gursky, who was arrested in the VUPL case, on his differences with the position of the VUPL on the issue of concentrated logging in the Ukrainian forests formed the basis of the trumped up investigation by the management of the management of the pest management of forest management ${ }^{30}$.

28 Barvish E. D. (1930) Pidsumky 1-gho Ob'jednanogho Vseukrajinsjkogho z'jizdu profspilky lisdrevrobitnykiv [Results of the 1st United All-Union Congress of the Forest Workers Union]. Ukrajinsjkyj lisovod [Ukrainian arborist]. № 10/12. Pp. 9-13.

${ }^{29}$ Protokol doprosa V. Y. Gurskogo ot 27.09.1929 g. [Protocol of interrogation of V. Y. Gursky on 09/27/1929]. OGA SB Ukrainy [BSA SS of Ukraine]. D. 68461. Vol. 1. P. 1. (unpublished)

30 Pokazaniya V. Y Gurskogo na doprosakh v sentyabre - noyabre $1929 \mathrm{~g}$. [Testimony of V. Y. Gursky during interrogations in September - November 1929]. OGA SB Ukrainy [BSA SS of Ukraine]. D. 68461. Vol. 1. Pp. 33-35. (unpublished) 
Another rule of this cruel game was this: each of the suspects had to give any of the real facts the most negative interpretation for themselves (to speak for themselves). How wild is such an acknowledgment of A. I. Kolesnikov: "When I got from the student's bench in the teaching environment of old times, I wanted to achieve a privileged social position, material well-being, which I had not had before, forgetting about the interests and needs of the workers from whom I came" 31 . According to the logic of the investigation, belonging to the ranks of the intelligentsia, and even the presence of a certain worldview in a person was already considered a pledge of criminal acts on her part. To master these rules and begin to implement them for the death of himself and his colleagues did not succeed all and not at once. At the first interrogations, they were arrested mostly for no fault of themselves or for others. And only later, withstanding the blackmail, provocations, physical pressure of the investigators, began to expose everyone and everything, without excluding themselves. Here is the testimony of B. A. Shustov of February 5, 1930: "What is useful to the Proletarian State in general and what to do in my area of specialty - I firmly knew and knew, but did not intentionally do it" ${ }^{\prime 32}$. When inventing evidence of his own wreckage was no longer enough fantasy, it was possible to be released, as A. I. Kolesnikov did: "I silently contributed a share of wreckage to this case",33.

As a result of consideration of the materials of the archival investigation, we can assume such a course of events. Interrogations of witnesses concerning the activities of the VUPL began as early as September 1929. The information they provided allowed the GPU

31 Svidetel'stva A. I. Kolesnikova na doprose ot 07.02.1930 g. [Testimonies of A. I. Kolesnikov during interrogation of 02/07/1930]. OGA SB Ukrainy [BSA SS of Ukraine]. D. 68461. vol. 2. p. 419. (unpublished)

32 Svidetel'stva B. A. Shustova na doprose ot 05.02.1930 g. [Testimonies of B. A. Shustov during interrogation of 02/05/1930]. OGA SB Ukrainy [BSA SS of Ukraine]. D. 68461. vol. 2. p. 391. (unpublished)

33 Stenograficheskiy otchet o zasedanii chrezvychaynoy sessii Verkhovnogo Suda USSR po delu o vreditel'stve v lesnom khozyaystve Ukrainy ot 14.06.1930 g. [Verbatim record of the meeting of the extraordinary session of the Supreme Court of the Ukrainian SSR on the case of wrecking in the forestry of Ukraine from 06/14/1930]. OGA SB Ukrainy [BSA SS of Ukraine]. D. 68461. vol. 3. p. 630. (unpublished) 
investigator to identify possible actors in the future litigation. Numerous testimonies obtained from ordinary forestry workers in the course of dozens of interrogations have led to accusations against reputable forest scientists and forest managers in Ukraine.

One of the first was arrested by the Head of the Department of Forestry and Timber Reclamation Department of the VUPL Valerian Gursky (November 16, 1929) and the Head of the Forest Management Department Ivan Kovalenko (December 18, 1929). These were the ones who later "beat out" the largest number of accusations (Gursky was summoned for interrogation 19 times, and Kovalenko - 25). Their written testimonies were so detailed and full of details that, on their basis, it was conceivable that it would be possible to draw up a concise account of the work of the VUPL for the entire period of its existence. Then there was the head of the Bureau of Economic Statistics of the VUPL, Boris Padalko. With the arrest, a new year began in 1930, for the head of the forest subdivision of the State Planning Committee of the USSR, Alexander Marchenko. On January 20, Boris Shustov, the head of the Forest Management Commission at the Forest Management Department of the VUPL, was hit in the cell, and eight days after that, the Deputy Chief of the VUPL, Alexander Kolesnikov, was at the camera.

The purpose of the investigation was to bring as many facts as possible to the detriment of the accused. It was only necessary to obtain from the detainees' recognition in political views other than the official, as all the years of ascetic work far removed from the policy of people from the rescue of Ukrainian forests, the development of forestry science and forestry turned into a total wicked pest. The process of forming the VUPL was presented as a criminal conspiracy by counterrevolutionaries led by emissaries from Moscow. In fact, the All-Ukrainian Forest Management was in fact presented as a subversive organization that served as a cover for counterrevolutionary activity.

And the fruitful work of experienced forestry professionals was proof of their affiliation with the counter-revolutionary organization.

And the more they carried out this work with more energy and perseverance, the more, by the logic of the investigation, the 
country was harmed. By manipulating the facts, the investigation managed to paint a horrific picture of wreckage in virtually all areas of the counter-revolutionaries. Among the activities of the "pests" were forestry and research, seed production, forest management (in terms of the indictment), forest export, training of "red" personnel for forestry management, activities of the forestry journalist, forest policy and planning.

At the same time, the facts presented in the testimonials were mostly true, which cannot be said about their interpretation. Therefore, in the archival investigative materials you can find interesting documents reflecting the problems of a number of forestry sectors of the time. Much previously unknown details can be found in the investigation protocols and biographies of forest science fossils. Valuable for researchers of archival sources in the history of forestry may also be specimens of the handwriting of the subjects, who mostly wrote their testimonies and each page bore its own signature.

\section{Professor Boris Shustov and the development of domestic forest taxation}

The closed court session without the participation of lawyers and witnesses took place on 14 June 1930. The wholehearted admission of his guilt or his refusal did not have a significant effect on the sentencing of the defendants [Indictment]. According to the sentence of the Supreme Court of the USSR, in accordance with Article 54-7 of the Criminal Code of the USSR, B. P. Padalka - the only defendant who pleaded guilty - received 4 years of imprisonment "in public places". I. S. Kovalenko and O. G. Marchenko were sentenced to 5 years. A. I. Kolesnikov and B. A. Shustov received 6 years each, although the court found their "sincere repentance" a mitigating circumstance. The least (3 years) was awarded to V. Y. Gursky, considering his "sincere repentance, old age and a comparatively minor role in counter-revolutionary pest activity",

${ }^{34}$ Prigovor suda po Delu VUPL [Sentence of the court on the case of VUPL]. OGA SB Ukrainy [BSA SS of Ukraine]. D. 68461. Vol. 2. P. 668. (unpublished) 
This case was perhaps the first in a series of similar cases that were pursued by foresters and foresters throughout the USSR. Frankly, for the purpose of the detailed campaign, he pointed out in the 10th issue of the Bolshevik magazine for the 1932 USSR Forest Industry Commissar S. S. Lobov: "The introduction of scientific principles into forestry practice would inevitably lead to the disruption of the tasks of the forest industry deployment, so on the consumption of forest science and all there Morozov and Orlov. No estimated logs. To cut down on need, despite the wisdom of forest scientists" 35 .

In the years that followed, the adherents of the classic forestry system were attacked by an avalanche of pseudoscientific publications by angry forestry "innovators". Following his drug addict M. Alexeychyk and B. Chagin in their work "Against reactionary theories on the forest front. Criticism of the teaching of prof. Morozov and Orlov and their followers" blamed well-known scientists and practitioners for insisting on the reactivity of the theory of sustainability and uniformity of forestry of M. M. Orlov and the Morozov principle of the stability of the plantations and the independence of the forest, emphasizing their anti-Soviet orientation ${ }^{36}$. Further, the aforementioned work contains a very strange invective: "The economic and political restoration of the landlord system in Russia is the content of a candid statement by the defiant defender of reactionary ideas G. F. Morozov (this is 12 years after the death of the aforementioned forestry classic!)" ${ }^{\prime 37}$.

Even the subtitle of the book is astonished by the modern reader: "The idealistic teaching of Prof. Sukachev on the typology of the forest and its critique", "Landlord-capitalist principle of sustainability and one-dimensional use of prof. Orlov and our Soviet forest industry". The authors' argumentation was "indisputable": "The Morozovsky

35 Furdychko O. I., Bondarenko V. D. (2000) Pershopostati ukrajinsjkogho lisivnyctva. P. 31-32.

36 Alekseychik N. (1932) Protiv reaktsionnykh teoriy na lesnom fronte. Kritika ucheniya prof. Morozova i Orlova i ikh posledovateley [Against reactionary theories on the forest front. Criticism of the teachings of prof. Morozov and Orlov and their followers]. Moscow: Goslestekhizdat. P. 153.

${ }^{37}$ Alekseychik N. (1932) Protiv reaktsionnykh teoriy na lesnom fronte. P. 154. 
doctrine of the forest as a whole is reactionary. It is in sharp contradiction with the socialist practice of our economy"38. Numerous court "theorists" of forestry, without sparing the forces, brought the base into practice the destruction of forest resources of the country.

What has been achieved through this process for those who shaped forest policy in the country of the victorious proletariat? First, they have demonstrated that neither scientific authority nor years of diligent work give professionals even the highest rank the right to their own opinion, and even more so the right to defend it freely. Secondly, that neither the human fate nor the fate of our forests is of any importance to revolutionary expediency. For years, "The forest is cutting down wood chips are flying!" has become the norm of life, an excuse for the cruelty and injustice in the life of Soviet society.

This lawsuit has caused irreparable harm to both the Ukrainian forestry and its best representatives, grossly detached from their inspired service to the cause of their lives. As a result of the repression of foresters, Ukrainian forests were deprived of their faithful defenders, and systematic and large-scale violation of forest management principles led to the destruction of the ecosystem of forest-steppe and steppe zones of agriculture.

Not only did political repression cripple the fate of individuals, hamper the development of national science, destroy the economy, but also for many years distorted the moral and intellectual atmosphere in the country.

In the work list of B. A. Shustov, who is also in the family archive and is happily preserved, contains the entry: "Arrested GPU 20.01.1930". The following entry tells us that in the period from 12.11.1931 to 18.04. In 1937, B. A. Shustov was a senior researcher at the Research Institute of Forestry and Agricultural Land Reclamation in Kharkov (the so-called "sharashki").

From 1937 he took the position of the head of the Department of Forest Taxation at the Bryansk Forestry Institute.

${ }^{38}$ Alekseychik N. (1932) Protiv reaktsionnykh teoriy na lesnom fronte. P. 44. 
During World War II, Shustov was in an evacuation, working at the Voronezh Forestry Institute, located in the village of Lubyany, Tatar ASSR. In the spring of 1944 he returned to Bryansk, the Bryansk Forestry Institute. He died in Bryansk on January 30, 1945. The tomb was not preserved; a park was destroyed at the site of the cemetery. In 1991 he was completely rehabilitated by the Security Service of Ukraine.

\section{CONCLUSIONS}

The development of domestic forest taxation in the first half of the $\mathrm{XX}$ century is connected with the name of B. A. Shustov. In this area Shustov is known for his research on the study of the growth of forest plantations and the compilation of mass tables. After a break of more than 50 years since the time of Vargas de Bedemar, the beginning of the XX century. marked by a revival of attention to research on the growth of plantations. In 1909, the first work of B. A. Shustov appeared on the course of growth of oak high-barrels in the Tula and Mogilev provinces. In 1914, materials were published on the course of growth of overgrown oak stands in southern Russia. These were the first significant scientific works in the agricultural literature in the course of oak growth. Experimental material for them was collected by Boris personally, making a number of trips during the period 1908-1914. Thus, to study the growth of overgrown oak they were laid 55 test areas in Voronezh, Kursk, Kharkov, Kiev and Podolsk provinces.

B. A. Shustov compiled experimental and mass tables of trunk volumes in seed and overgrown oak plantations. Previously, German tables were used. In 1912, together with M. M. Orlov, he compiled tables "Volume and bends of pine trunks", built on a large experimental material of 5400 model trees. They replaced the tables of 1886 and the tables of A. A. Kruedener.

In 1923-1931, Professor B. A. Shustov made mass and assortment tables for taxation of all forest species of Ukraine (pine, oak, ash, birch, alder, aspen and hornbeam). In 1926 Shustov studied the course of growth of pine plantations in Ukraine, as well as compiled experimental tables of volumes of trunks. 
In 1931, official mass tables of volumes of trunks for oak (planting material) by bonus classes (discharges), compiled by Shustov on the experience of all his previous research, were published.

Finally, in 1939, B. A. Shustov compiled assortment tables for pine and spruce (planting material) of the Bryansk Forest. Massive volume tables of trunks of different tree species, along with the experience and growth charts of overgrown oak plantations, were included in the forest management directories and greatly benefited the organization and planning of the forestry.

Since 1931, B. A. Shustov has paid much attention to the issues of logging. As early as 1908, he laid out forest care trial areas in the Tula province, and in 1914 he re-taxed them. Since 1933, there have been a number of original works by Shustov on the history and practice of felling in oak and hornbeam plantations, based on extensive experimental material.

It was B. A. Shustov who was one of the first in the USSR to develop the problems of felling. This is the main agricultural technique of growing forests. They grow for about 100 years, so to get as much wood as possible every 10 years, they cut down the trees - they cut down dry, unhealthy, weakened trees, as well as trees that prevent the growth of the most promising specimens. Knowing what and how much to cut is very important, because it depends on the end result. Shustov was an advocate of the active influence of foresters on the formation of plantations ${ }^{39}$.

The theory of forest taxation is also the work of Shustov in determining the volume of tree trunks using a new formula and to develop a method of taxation and determine the stock of plantations without felling trees (1932).

In total, B. A. Shustov prepared about 50 and published 40 works. Their distinguishing feature is the connection of theory with practice, absorbed by the desire of the scientist to provide substantial assistance

39 Kotov A. I., Pamfilov V. V. (1960) Pamyati professora B. A. Shustova (k 15-letiyu so dnya smerti) [In memory of Professor B. A. Shustov]. Trudy Bryanskogo tekhnologicheskogo instituta [Proceedings of the Bryansk Technological Institute]. Vol. IX. Pp. 346-348. 
to production, and this is one of its great merits. This is his desire to explain the compilation of various collections: auxiliary tables for taxation of the forest, auxiliary tables for calculations in the forestry and satellite taxis.

\section{SUMMARY}

The era in which Professor Boris Shustov had to live and work was characterized by great drama and controversy. This fact greatly complicates her historiographical study. The ideological pressure of the totalitarian state, on the one hand, deprived the researchers of the possibility of objective consideration of historical phenomena, and on the other - derived from the scientific circulation huge arrays of primary sources. As for published historiographical works, their political writers often deliberately omitted the most poignant and dramatic episodes of the events of the history and biographies of its protagonists and covered the phenomena quite one-sidedly. There was a strong underestimation of the role of the creative personality in the development of society, which gave rise to a lack of attention to the study of the life and activities of prominent representatives of national science, technology and art. Probably, these factors were the reason why the powerful figure of scientist and organizer of science, teacher and practitioner B. A. Shustov remained in the shadows. Meanwhile, the opportunity to look at historical processes through the lens of the biography of a particular person allows you to open up new research horizons. History becomes specific and personified, it acquires a human face.

The moral aspect of biographical research is important: paying tribute to the figures of past years, the society is demonstrating to the new generations the exemplars of ascetic service in the chosen cause and motivating the young in their life choices.

In the course of analyzing the facts of a biographical order, it is extremely important to constantly relate them to the events of macrohistory, to write them in a historical outline. This allows you to uncover many of the causal relationships that have caused this or that turn of fate. It is these methodological approaches that underpin the work devoted to the life and activities of Professor B. A. Shustov. 


\section{REFERENCES}

1. Vakuljuk P. G. (1994) Sprava VUPLu [The case of VUPL]. Kiev: [b. v.]. (in Ukrainian)

2. Vakuljuk P. G. (1998) Reabilitovani istorijeju [Rehabilitated by History]. Kiev: [b. v.]. (in Ukrainian)

3. Vakuljuk P. G. (2004) Lisivnyky - zhertvy totalitarnoji systemy [Foresters are victims of the totalitarian system]. Kiev: Ukrcentrkadrlis. (in Ukrainian)

4. Vakuljuk P. G. (2005) Lisnychyj - gholovnyj ghospodar lisu [Foresters are the chief forest manager]. Kiev: Ukrcentrokadrlis. (in Ukrainian)

5. Vakuljuk P. G. (2006) Lisovidnovlennja ta lisorozvedennja v Ukrajini [Reforestation and deforestation in Ukraine]. Kharkov: Prapor. (in Ukrainian)

6. Furdychko O. I., Bondarenko V. D. (2000) Pershopostati ukrajinsjkogho lisivnyctva. Narysy do lisovoji istoriji [The First Figures of Ukrainian Forestry. Essays on forest history]. Lviv: Bibljos. (in Ukrainian)

7. Boreyko V.E. (2003) Belye pyatna prirodookhrany [White spots of Nature Conservation]. Kiev: Logos. (in Russian)

8. Kasjjanov V. G. (1992) Ukrajinsjka intelighencija 1920-kh 1930-kh rokiv: socialjnyj portret ta istorychna dolja [Ukrainian Intelligence of the 1920s - 1930s: A Social Portrait and a Historical Destiny]. K.: Ghlobus. (in Ukrainian)

9. Delo VUPL. Otraslevoy gosudarstvennyy arkhiv Sluzhby bezopasnosti Ukrainy (OGA SB Ukrainy) [Case of VUPL. Branch State Archive of the Security Service of Ukraine (BSA SS of Ukraine)]. D. 68461. Vol. 1-3. (unpublished)

10. Protokol sudebnogo zasedaniya ot $14.06 .30 \mathrm{~g}$. [The record of the court hearing of June 14, 30]. OGA SB Ukrainy [BSA SS of Ukraine]. D. 68461. Vol. 2. P. 630. (unpublished)

11. Arkhivnyj fond Chernighivsjkoji dukhovnoji konsystoriji f. 679, op. 10, spr. 317, ark. 440 zv. [Archive Fund of the Chernigiv Spiritual Consistory. F. 679. Op. 10. Sp. 317, arch. $440 \mathrm{zv].} \mathrm{(unpublished)}$ 
12. Triputina N. P. (2011) Professor A. I. Kolesnikov: stranitsy zhizni $i$ deyatel'nosti [Professor A. I. Kolesnikov: pages of life and activity]. Kharkov: KhNAGKh. (in Russian)

13. Vakuljuk P. G. (2000) Narysy z istoriji lisiv Ukrajiny [Essays on Forest History Ukraine]. Fastiv: Polifast. (in Ukrainian)

14. Pyatnitskiy S. S. (1966) Istoricheskiy ocherk fakul'teta lesovodstva [History of the Faculty of Forestry]. 150 let Khar'kovskomu ordena Trudovogo krasnogo znameni sel'skokhozyaystvennomu institutu im. V. V. Dokuchaeva (1816-1966) [150 years of the Kharkov Order of the Red Banner of Labor Agricultural Institute. V. V. Dokuchaev (1816-1966)]. Pp. 87-104.

15. Obvinitel'noe zaklyuchenie po "Delu VUPL" [Indictment on VUPL Case]. OGA SB Ukrainy [BSA SS of Ukraine]. D. 68461. Vol. 2. Pp. 186-187. (unpublished)

16. Zaklyuchenie Prokuratury g. Kieva ot 20.12.1990 g. v otnoshenii Kolesnikova A. I. po materialam ugolovnogo dela [The conclusion of the Prosecutor's Office in Kiev dated 12/20/1990 in relation to A. Kolesnikov based on the materials of the criminal case]. OGA SB Ukrainy [BSA SS of Ukraine]. D. 68461. Vol. 2. P. 23. (unpublished)

17. Protokol obshchego sobraniya studentov KhSKhI [Protocol of the general meeting of students of the KhSKhI]. Derzhavnyj arkhiv Kharjkivsjkoji oblasti [The State Archive of Kharkiv Oblast]. F. R-1148. Op. 7. D. 37. L. 52. (unpublished)

18. Romanivsjkyj I. (1930) Na borotjbu z kontr-revoljucijnym shkidnyctvom [To combat counter-revolutionary wreckage]. Ukrajinsjkyj lisovod [Ukrainian arborist]. № 4. Pp. 1-4.

19. Dashkevych L. (1930) Za proletarsjki kadry [For the proletarian cadres]. Ukrajinsjkyj lisovod [Ukrainian arborist]. № 10/12. Pp. 8-9.

20. Najsuvorishoji kary ghrupi shkidnykiv-specialistiv v siljsjkomu ta lisovomu ghospodarstvi Ukrajiny: postanova prezydiji VUKu SGhLR pro shkidnycjku orghanizacijeju v siljsjkomu ta lisovomu ghospodarstvi Ukrajiny (1930) [The harshest punishment for a group of pests-specialists in agriculture and forestry of Ukraine: the decision of the Presidium of VUK of the SGLR on a pest organization 
in agriculture and forestry of Ukraine]. Ukrajinsjkyj lisovod [Ukrainian arborist]. № 4. Pp. 5-6.

21. Ivanycjkyj B. G. (1936) Lisy i lisove ghospodarstvo na Ukrajini [Forests and forestry in Ukraine]. T. 2. Varshava. (in Ukrainian)

22. Red'ko G. I. (2002) Istoriya lesnogo khozyaystva $v$ Rossii [History of forestry in Russia]. Moscow: MGUL. (in Russian)

23. Ghuba A. (1929) Na novi rejky [On new rails]. Ukrajinsjkyj lisovod [Ukrainian arborist]. № 12. Pp. 27-31.

24. Tkach V. P., Mjeshkova V. L. (ed.) (2005) UkrNDILGhA [UkrNDILGhA]. Kharkov: UkrNDILGhA. (in Ukrainian)

25. Barvish E. D. (1930) Pidsumky 1-gho Ob'jednanogho Vseukrajinsjkogho z'jizdu profspilky lisdrevrobitnykiv [Results of the 1st United All-Union Congress of the Forest Workers Union]. Ukrajinsjkyj lisovod [Ukrainian arborist]. № 10/12. Pp. 9-13.

26. Protokol doprosa V. Y. Gurskogo ot 27.09.1929 g. [Protocol of interrogation of V. Y. Gursky on 09/27/1929]. OGA SB Ukrainy [BSA SS of Ukraine]. D. 68461. Vol. 1. P. 1. (unpublished)

27. Pokazaniya V. Y. Gurskogo na doprosakh $v$ sentyabre noyabre $1929 \mathrm{~g}$. [Testimony of V. Y. Gursky during interrogations in September - November 1929]. OGA SB Ukrainy [BSA SS of Ukraine]. D. 68461. Vol. 1. Pp. 33-35, 37, 41. (unpublished)

28. Svidetel'stva A. I. Kolesnikova na doprose ot 07.02.1930 g. [Testimonies of A. I. Kolesnikov during interrogation of 02/07/1930]. OGA SB Ukrainy [BSA SS of Ukraine]. D. 68461. Vol. 2. P. 419. (unpublished)

29. Svidetel'stva B. A. Shustova na doprose ot 05.02.1930 g. [Testimonies of B. A. Shustov during interrogation of 02/05/1930]. OGA SB Ukrainy [BSA SS of Ukraine]. D. 68461. Vol. 2. P. 391. (unpublished)

30. Stenograficheskiy otchet o zasedanii chrezvychaynoy sessii Verkhovnogo Suda USSR po delu o vreditel'stve v lesnom khozyaystve Ukrainy ot 14.06.1930 g. [Verbatim record of the meeting of the extraordinary session of the Supreme Court of the Ukrainian SSR on the case of wrecking in the forestry of Ukraine from 06/14/1930]. OGA SB Ukrainy [BSA SS of Ukraine]. D. 68461. Vol. 3. P. 630. (unpublished) 
31. Prigovor suda po Delu VUPL [Sentence of the court on the case of VUPL]. OGA SB Ukrainy [BSA SS of Ukraine]. D. 68461. Vol. 2. P. 668. (unpublished)

32. Alekseychik N. (1932) Protiv reaktsionnykh teoriy na lesnom fronte. Kritika ucheniya prof. Morozova i Orlova i ikh posledovateley [Against reactionary theories on the forest front. Criticism of the teachings of prof. Morozov and Orlov and their followers]. Moscow: Goslestekhizdat. (in Russian)

33. Kotov A. I., Pamfilov V. V. (1960) Pamyati professora B. A. Shustova (k 15-letiyu so dnya smerti) [In memory of Professor B. A. Shustov]. Trudy Bryanskogo tekhnologicheskogo instituta [Proceedings of the Bryansk Technological Institute]. Vol. IX. Pp. 346-348.

\section{Information about the author: Yuliia Dobrolyubska,}

Doctor of Sciences in Philosophy, Professor, Head of the Department of World History and Methodology of Science, South Ukrainian National Pedagogical University named after K. D. Ushinsky 26, Staroportofrankovskaya str., Odessa, 65020, Ukraine ORCID ID: orcid.org/0000-0002-3564-854X 


\section{PERCEPTIONS OF THE PROBLEMS OF THE JEWISH POPULATION IN ODESSA JOURNALISM IN THE 50-60 OF 19TH CENTURY}

\section{Olga Likhachova}

\section{INTRODUCTION}

The preparation of the socio-economic and political reforms of the second half of the 19 th century, which took place in the Russian Empire, led to significant changes in journalism and publishing. During this period, the government pursued a dual policy towards the press. On the one hand, when discussing transformation projects, they were interested in new ideas and approaches to solving problems that the press could provide. On the other hand, the authorities feared widespread discussion of state reform. In the late $1950 \mathrm{~s}$ and early $1960 \mathrm{~s}$, the issue of giving equal rights to Jews was urgently raised in journalism. This was triggered by a series of measures outlined by the government- on the one hand, and the emergence of literary public printing bodies- on the other. During this period Odessa became one of the most important cities in which the Jewish Enlightenment movement - the Haskalah - developed. Thus, the analysis of this regional press provides opportunities to consider a number of questions, both about the progress of reforms in the country and about the history of the formation of the liberal press and journalism in Odessa. The article presents an analysis of the positions of the periodicals of the "Odesskiy vestnik" and the "Rassvet" magazine on these issues. The Odessa Vestnik was founded in 1827 and was subject to the jurisdiction of the Office of the Governor-General. Until the mid 50 's of the XIX century. The "Odesskiy vestnik" was considered one of the oldest, most respected official press agencies in the Russian Empire. However, in its content, this newspaper was a little different from other publications that reported local news. It contained decrees reprinted from St. Petersburg newspapers, as well as official orders from local authorities. But after coming in 1856 to the post of the head 
of the Odessa educational district M. I. Pirogov, "Odesskiy vestnik" was transferred to the leadership of the Richelieu Lyceum. Despite the difficult censorship restrictions, the editorial staff of "Odesskiy vestnik" managed to change qualitatively the subject matter and ideological orientation of this newspaper. The "Odesskiy vestnik" has acquired a bright liberal orientation. The liberal-democratic orientation of the newspaper was most clearly reflected in the coverage of the problems of the Jewish population. The pages of Rassvet, the first Russian-language Jewish magazine, have been able to formulate a comprehensive program of necessary transformations to address the issue of emancipation of Jews in the Russian Empire. As an example of a vivid examination of the problems of Jews by Odessa publicists, the historical and journalistic "Essay on the Contemporary History of Judaism" by O.I. Georgievsky is analyzed. Consideration of issues of perception and reflection in the Odessa press and journalism of acute issues of reform of Jewish communities will give an opportunity to make a general picture of the vision of the further liberal development of Jewish society by the Odessa liberal press during this period.

\section{Formation of Views on the Problems of Reforming Jewish Communities in Odessa Journalism in 50-60 of 19th Century}

The question of the emancipation of the Jewish population arose in the late 1950s sharply. It is known that since March 1856 "Committee for Determining Measures of Indigenous Conversion of Jews in Russia" under the leadership of Count P. D. Kiselev resumed its work. With the direct involvement of P. D. Kiselev, the Committee has taken a course to improve the legal status of Jews, however, taking into account property or educational qualifications. The Committee proposed to gather the views of the Governors-General on the Jewish issue. Particular attention was paid to the position of the Novorossiysk and Bessarabian governor-general - the Count O. G. Stroganov, who advocated the equalization of Jews in their rights with Christians.

This proposal was supported by Minister of the Interior S. S. Lansky. However, this approach was rejected by the Committee. An important role was played by the position of a new head, Count D. M. Bludov, who advocated gradual steps in addressing this issue. However, on March 16, 
1859, a decree was issued granting the right of universal residence to Jewish merchants of the 1st Guild. The Committee has widely discussed the possibility of resettlement and other categories of the Jewish population ${ }^{1}$. Thus, even those brief testimonies pointed to the fact that during this period, it was in the south of the Russian Empire that a special social atmosphere was created, which contributed to the emergence of progressive views on the problems of the Jewish population. Let us turn to the analysis of the factors that led to such a course of events. It should be noted that it was Odessa, its public figures, journalists, and publicists who made a significant contribution to the discussion of these issues. In 1856 M. I. Pirogov was appointed as the head of the Odessa educational district. He initiated the transition of the "Odesskiy vestnik", a newspaper that was founded in 1827 and was subject to the jurisdiction of the Office of the Governor-General under the leadership of the Richelieu Lyceum. His idea was that the newspaper, under the editorship of the professors of this institution, would be a powerful source of education for the whole province. O. G. Stroganov, who held the position of Governor-General during this period, at first supported this idea. According to the decision of the Lyceum, young teachers O. M. Bogdanovsky and O. I. Georgievsky were appointed as editors of the "Odesskiy vestnik". Under the new edition, the newspaper began to be published on January 4, 1858. Three issues of the newspaper were published weekly. It should be emphasized that since this period the newspaper has completely changed the range of considered issues. One of the main issues discussed periodically on the pages of this publication was the issue of the Jewish population. M. I. Pirogov was one of the first to address these problems. His article was published in the spring of 1858 under the title "Odessa Talmud-

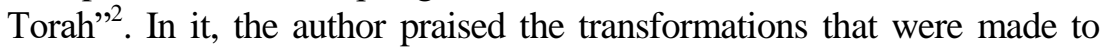
charity at an educational institution where orphans and low-income families were educated. The trustee of the educational district considered the experience of the "Odessa Talmud-Torah" extremely important not only for Jewish educational institutions but also triggered extending the

${ }^{1}$ Mindlin, A. B. (2005) Imperator Aleksandr II i “evreyskiy vopros" [Emperor Alexander II and the Jewish Question]. Paralleli - Parallels, 6, 23-26 [in Russian]

${ }^{2}$ Pirogov M. I. (1858) Odesskaya Talmud-Tora [Odessa Talmud-Torah].

Odeskiy vestnik - Odessa Herald, 26, 1-2 [in Russian] 
example of charity raising to other schools. All the ideas of M. I. Pirogov were fully understood and supported in the edition of the "Odesskiy vestnik". The editorial board of the "Odesskiy vestnik" encouraged discussions of prominent Jewish figures on the pages of the newspaper. Many Jewish authors began to publish their articles in the newspaper: J. Rabinovich, I. Tarnopol, and others. For the first time, a Jewish issue was covered so widely on the pages of a Russian-language newspaper. In 1858 , more than ten articles were devoted to this problem. Gradually, on the pages of the "Odesskiy vestnik", the personal attitude of the editorial staff in solving the main problems of the Jewish population was born. The "Odesskiy vestnik" has repeatedly emphasized the need for rapprochement between Jews and other nations, it was only possible as a result of success in the education system on both sides. The editorial position on the Jewish theme has caused serious resonance not only in the local but also in the capital's press. Governor-General O. G. Stroganov was also dissatisfied with the activities of the trustee of the educational district M. I. Pirogov, and the edition of the "Odesskiy vestnik". In February 1858, he wrote to the Minister of Public Education that the positions of the new edition of the newspaper lead to the development of the harmful direction. A. Egorov (Konsparov), a memoirist, who held various positions in the censorship organizations of the Russian Empire for many years, wrote in his illustrated documentary about the difficult situation surrounding the "Odesskiy vestnik" ${ }^{3}$. Even though the newspaper was published on favorable terms for the city treasury, namely, refused the proceeds of the publication in favor of the printing press and paid the Lyceum 1500 rubles annually, the local government decided to get rid of it $^{4}$. The reason was found in numerous remarks of the General Directorate of Censorship in St. Petersburg. It repeatedly condemned and reprimanded the local Odessa censors for publications of the "Odesskiy vestnik". In this regard, it was decided to re-transfer the "Odesskiy vestnik"to the

3 Egorov, A. (Konsparov) (1913) Stranitsy iz prozhitogo [Pages from lived]. Odessa: "Slavyanskaya" tipografiya E. Khrisogelos [in Russian]

${ }^{4}$ Grebtsova, I. S. (2002) Periodicheskaya pechat' v obshchestvennom razvitii

Yuzhnogo stepnogo regiona Rossiyskoy imperii (vtoraya tret' XIX v.) [Periodic press in the social development of the Southern steppe region of the Russian Empire (second third of the 19th century]. Odessa: Astroprint [in Russian] 
Governor-General. In the last issue of the newspaper, the editorial board summarized its activities, stating: “... We worked hard and didn't work for nothing: we proved... that in the provinces, not in some capitals, true literary and journalistic activity is possible..." 5 . It should be noted that the new collection was dedicated to M. I. Pirogov, who by this point had already been transferred to the post of trustee of the Kyiv Educational District. A new collection has also found a place in Jewish journalism. On its pages, an article by J. Rabinovich "On the Names of Jews " was published, which is considered one of the first examples of Jewish scientific and journalistic activity on the pages of the Russian-language edition. Note that the new collection was dedicated to M. I. Pirogov, who by this point had already been transferred to the post of trustee of the Kyiv Educational District. And in many respects, this new appointment was linked to his liberal views on the problems of the emancipation of the Jewish population. But after M. I. Pirogov left Odessa, he did not neglect the problem of Jewish periodicals. He endorsed the main goals of the new edition: the education and equality of Jews in the Russian Empire. The journal was supposed to publish materials on the life of Jews, their historical past, as well as articles on current issues. In his letter to the publishers of a new magazine published in one of his issues, M. I. Pirogov noted: "Whatever side we look at for Jewish people, there is no rational reason why we would not want what we want to ourselves: respect for the beliefs of conscience, for the individual, for the merits of everyone, there is no reason why we would not want the Jews to benefit from our common homeland and enjoy its benefits for that reason... without passion for everything truly human, they must open their new regular ranks for all burdened with the struggle for universal enlightenment... I do not need to explain to what extent I sympathize your publication. God forbid that it may spread a view similar to the one I have outlined ${ }^{6}$. And it is even more desirable than the "Rassvet", with the assistance of the thoughts and beliefs, would serve to unite and interact with all educated Jews. Thus, the new foundations of the magazine "Rassvet" were laid, which began to be

5 Bogdanovskiy, A., \& Georgievskiy, A. (ed.) (1858) Peredovaya stat'ya [Editorial]. Odesskiy vestnik - Odessa Herald, 119, 1 [in Russian]

${ }^{6}$ Bogdanovskiy, A., \& Georgievskiy, A. (ed.) (1859) Novorossiyskiy literaturnyy sbornik [Novorossiysk literary collection]. Odessa: P. Frantsova. [in Russian] 
published in Odessa on May 27, 1860. This magazine became the first Jewish periodical to be published in the Russian Empire. Its publishers were J. Rabinovich and I. Tarnopol. A whole galaxy of talented publicists and scholars has been involved in publishing. Within the magazine, the authors such as I. Yost and S. Pinsker and ordinary representatives of the Jewish community of the city were able to print their works. O. I. Georgievsky became one of the active participants of the editorial board and presenter of a regular column of the magazine under the name "Review of Foreign Jewish Journalism".

The editorial board viewed him as a talented journalist and publicist. Moreover, his role in the publication of the magazine was recognized as brilliant even by people who were dissatisfied with the actions of the editorial staff. Thus, one of the issues of the magazine contained a letter from an angry author who did not find his material in the published issue and was convinced that he was not allowed by O. I. Georgievsky. Nevertheless, he wrote: “ O. I. Georgievsky has a brilliant talent, it is not surprising that such a figure can be seen as a worthy employee of the editorial board of the magazine"7. It should be noted that this episode shows that the duties performed by O. I. Georgievsky were not limited to journalism, but also related to editing of the magazine. The magazine began to highlight major changes in the lives of Jews, based on an analysis of the most important European publications. The point was that the first issue had to be revised by censorship. Therefore, it was not possible to raise acute problems for the Jewish community. But the editorial board found a solution and talked about all the problems through the lens of Western European Jewry. At "Rassvet" there were translations of authors from German, French, Italian, English. About the benefit of this approach, the editorial wrote: "In literature in general, and in journalism specifically reflects the whole life of any people with its temporal and eternal, material and moral interests, pleasures and sorrow" ${ }^{\prime \prime}$. There was no doubt about the influence of journalism on the

\footnotetext{
7 Rabinovich, Y. (ed.) (1860) Pis'mo v redaktsiyu "Rassveta" [Letter to the editors of "Rassvet"]. Rassvet - Sunrise, 27, 432 [in Russian]

${ }^{8}$ Georgievskiy, A. (1860) Obzor inostrannoy evreyskoy zhurnalistiki [Review of Foreign Jewish Journalism] Rassvet - Sunrise, 1, 9-13 [in Russian]
} 
socio-political and spiritual component of society. Thus, "Rassvet" called for addressing the internal problems of Jewish society by examining similar problems of the Jewish world outside Russia. At the same time, the magazine insisted on the need not only to deal solely with the Jewish issue in the humanitarian sphere but also to pay attention to their contribution to the development of all European states through the diverse socio-economic activities of the Jews. Before that, according to the editorial board, there was every reason. "By their real and moral capital, Jews undoubtedly bring great benefit to the country that serves them as a native...", the journal noted ${ }^{9}$. In the developed countries of Western Europe, this process of disappearance of prejudice and hidden persecution against the Jewish community was gaining momentum during this period. Undoubtedly, this process was greatly facilitated by the active participation of Jews in the sociopolitical life of the countries in which they resided. Thus, one can distinguish the problem of the influence of the socio-political activity of the Jewish population on the development of the leading European countries as one of the most important problems addressed in several articles of the "Rassvet". Indeed, the magazine provided examples from the recent history of Western European countries that showed close co-operation with other nations, especially in the course of hostilities. The magazine wrote about the service of the Jews in the French National Guard. His articles contained examples from the lives of hundreds of Jews who joined D. Garibaldi's national liberation movement in Italy. Much attention was paid to the equation in the rights of the Jewish population of Lombardy, Parma, Modena, and Tuscany with other subjects after unification with Piedmont. According to the magazine, this process was a direct consequence of the fact that the Jews of these territories saw their future in the united national Italian state and fully contributed to its creation. Serious attention was paid to the issue of uniting Jews in European countries to protect their rights. Several articles were devoted to the various forms and methods of this activity. Thus, concerning the letter addressed to

\footnotetext{
${ }^{9}$ Georgievskiy, A. (1860) Obzor inostrannoy evreyskoy zhurnalistiki [Review of Foreign Jewish Journalism] Rassvet - Sunrise, 4, 55-57 [in Russian]
} 
the Jews of all countries by the Italian Jews who were oppressed by the Roman Curia, it was written in the journal: "We do not know yet whether this voice will despair the hearing of the Rothschilds, Pereira, Miressi, Goldemides, Montefiore, and others, the fact that we have presented is remarkable... because the idea of appealing to the oppression of Roman curia by fellow believers in all European countries is a product of modern times"10. Opposed to one of the important struggles of the Jewish people, "Rassvet" considered the idea of the creation of public-Jewish organizations. During this period, similar projects were discussed on the pages of the Common Judaism Newspaper, which outlined the idea of widespread governmental involvement in the creation of such organizations. With such a course of events, the edition of "Rassvet" could not stay positive about. According to the magazine, the initiative must have been raised by Jewish society and unite Jews in solving the most acute and serious problems. The magazine cited several high-profile cases that caught the attention of not only the Jewish population but also became known throughout Europe. These include the abduction of a Jewish child by Catholic priests in Bologna to raise her in the Christian faith, the escape of several thousand Jews from Morocco, the situation of Jews in the Danube principalities. Such difficult life situations, according to the editorial staff, helped to realize the unity between the Jews of all countries. The magazine argued that such unity would lead to the disappearance of national-religious differences if it were only about human interests and inalienable human rights. "More often the Jews, despite their displacement around the world, will have the opportunity to act at the same time and in their affairs, which arouse compassion among Christians. More they will be concerned with the consciousness of their unity and more they will come closer to Christians", was written in the journal ${ }^{11}$. The magazine paid particular attention to the situation in Gibraltar following the fleeing of four thousand Jews who were persecuted in Morocco. After a detailed examination of the

${ }^{10}$ Georgievskiy, A. (1860) Obzor inostrannoy evreyskoy zhurnalistiki [Review of Foreign Jewish Journalism] Rassvet - Sunrise, 5, 76-77 [in Russian]

${ }^{11}$ Georgievskiy, A. (1860) Obzor inostrannoy evreyskoy zhurnalistiki [Review of Foreign Jewish Journalism] Rassvet - Sunrise, 10, 156-159 [in Russian] 
history of this situation, the magazine with optimism emphasized: "But now the wounds inflicted by fanaticism and barbarism, if possible, have been immediately treated by education and philanthropy, without distinguishing between nationalities and religions" ${ }^{12}$.Fundraising has begun across Europe to support this mass of disadvantaged people. And the money was donated by Catholics, Protestants, and Jews. Based on the analysis of articles on the problems of the unification of Jews living in different states of Europe, we can trace the process of transforming the idea of editing a magazine about the benefits of charitable actions within Jewish communities to the idea of charity for the benefit of representatives of any nationality subject to national or religious oppression. As an example, one of the featured material about fanatical attacks on Christians in Syria. In this regard, the magazine highlighted the explicit approval of the proposals of the former member of the provisional government of France, a Jew by nationality, A. Premier to create a standing committee to oversee all encroachments on the freedom of conscience, and cash assistance to all victims of fanaticism. It should be emphasized that the problems of establishing charitable foundations and commissions, the need for Jews to be aware of their unity, especially in the face of the ongoing national conflicts, were of interest to the magazine and not about satisfying the curiosity of readers. The magazine addressed a serious and profound problem. According to the magazine, the high-profile cases, which excited the majority of Europeans without differences of nationality and religion, showed complete indifference to the Jews who lived in Russia. The editors noted: "We do not know of any pan-European cause in which Russian and Polish Jews are involved with the masses... All these disasters reach the hearing, but not to the hearts of Russian and Polish Jews: at least, they remain inactive" ${ }^{\text {"13 }}$. Editors suggested that such behavior may be due to fears of showing themselves more to Jews than to nationals. But this attitude, according to the magazine, namely the inaction in helping Syrian Christians cannot be justified.

${ }^{12}$ Rabinovich, Y. (ed.) (1860) Peredovaya stat'ya [Editorial] Rassvet - Sunrise, 21, 338 [in Russian]

${ }^{13}$ Georgievskiy, A. (1860) Obzor inostrannoy evreyskoy zhurnalistiki [Review of Foreign Jewish Journalism] Rassvet - Sunrise, 10, 156 [in Russian] 
The magazine expressed the optimistic opinion that the magazine's editorial board would increasingly be able to talk about the charity of both Jews and Christians in favor of Jews. Already in the next issue of the magazine was announced the start of fundraising for the benefit of Syrian Christians. In total collected 285 rubles of silver, of which 10 rubles were donated by the editorial board of "Rassvet". In the next group of articles, "Rassvet" addressed the problem of conservatism in the Jewish communities. It developed the view that many of the problems of the Jews were rooted in the orthodoxy of Jewish society, alert to any, even minor, changes. These traits, according to the editors of the magazine, often hindered progress. The magazine often used the example of Germany to confirm this position. According to "Rassvet", even though the process of reform of Judaism in this country was much faster than in other countries, but every step forward, every innovation met with strong resistance from the jealousy of antiquity. The need for change in Jewish society is also reflected in several publications on Moldovan Jews. Discussing in the articles the possible ways of the progressive development of the Jewish community, the editorial office of "Rassvet" directly linked this path with the new trends in education. Thus, there is another important issue that has been covered in journal articles. This was the problem of providing the Jewish population with modern education opportunities. The editorial staff was convinced that enlightenment is the key to the spiritual, moral and material well-being of present and future generations. The magazine directly stated this: "Schools that meet the multilateral needs of time are the true basis and the most reliable source of people's well-being" ". On the pages of "Rassvet" was presented a complete picture of the status of Jewish education in developed countries of Western Europe, its pros and cons were evaluated. Considering the situation in Austria and Galicia, the magazine noted that there is still a widespread education there with the help of melamed and heads. Not only this is bad for general education, but it leads to the decline of religious education, to the spread of Hasidism. About governmental measures, some considered the

\footnotetext{
${ }^{14}$ Rabinovich, Y. (ed.) (1860) Peredovaya stat'ya [Editorial] Rassvet - Sunrise, 21, 338 [in Russian]
} 
magazine ambiguous. For example, Jews were granted land titles only after they had completed their coursework. In this case, the magazine's editorial staff, fully aware of the government's objectives and supporting them, nevertheless disagreed with the coercive system. The magazine noted that Jews rarely concede to violent measures, they only cause violence in their environment.

As a result of a thorough discussion of the state of development of the Jewish communities, the journal identified the countries where the greatest progress was made in the education and emancipation of the Jews. Thus, the magazine has set the benchmarks that Jewish communities and the state should seek. According to the magazine, full religious freedom only met in the North American United States, where any religion hadn't had the right for assistance from the state. Also, to a smaller extent, in France, where, according to the magazine, the government patronized and assisted all religions. The magazine described a vivid episode about it. Namely, Napoleon III's gift to the Parisian Jewish community of the Torah scroll, solemnly introduced by the emperor himself in the main synagogue of Paris ${ }^{15}$. The analysis of European materials allowed the magazine to focus on the study of the education of Jews in Russia. The editorial staff noted, that we are convinced that there will be many capable and deserving administrators, judges, especially professors and teachers among Russian Jews, and when all these position become available to them, they will undoubtedly bring significant benefits to all branches of the civil service. Almost all magazine articles on Jewish education in Russia indicated a positive example of Jewish joint education with representatives of other nations and religions. The opportunity to receive a full-fledged modern education was considered by the magazine to be one of the foremost tasks for Jews living in the country. It should be noted that the views of the Dawn editorial board on changes in traditional Jewish education did not always coincide with those of orthodox Jewish leaders. They feared that any changes in this

\footnotetext{
${ }^{15}$ Rabinovich, Y. (ed.) (1860) Peredovaya stat'ya [Editorial] Rassvet - Sunrise, 46, 739 [in Russian]
} 
area would entail changes in the norms of Judaism and would adversely affect the national identity of the Jewish people ${ }^{16}$. However, studying the issue of Jewish education in Russia allowed the magazine's editorials to touch on another pressing topic. The magazine has repeatedly noted the negative impact of the artificial restriction on the residence of Jews throughout the Russian Empire on the habitation strip. The editors of the magazine were irreconcilable critics of the residency band, but because of censorship restrictions, they could address this topic only based on the experience of Western European countries. However, the attentive reader could easily see in the calls for the modernization of Jewish education, the possibility of obtaining a full-fledged, up-to-date education, above all, a call for the elimination of the lane. It should be noted that the dawn articles on the fastest possible solution to the problem of emancipation of the Jews, as well as the general liberal orientation of the editorial board, caused dissatisfaction with the local and central censorship bodies. This led to the closure of the magazine, the last issue of which was published May 19, 1861.

Thus, the pages of the "Odesskiy vestnik" and the magazine "Rassvet" reflected the current problems of the development of Jewish communities. Considerable attention was paid to the need for developing charity, which in turn would facilitate the development of public relations between Jews and Jewish communities, as well as the development of international relations. The complex of problems connected with obtaining modern secular education was considered. This issue made it possible to move on to the most significant problem - the elimination of the lane. In general, Odessa journalists managed to formulate a comprehensive program of necessary changes to address the issue of giving political and civil rights to Jews.

\footnotetext{
${ }^{16}$ Tsinberg, S. L. ( 1915) Istoriya evreyskoy pechati v Rossii v svyazi s obshchestvennymi techeniyami [The history of the Jewish press in Russia in connection with social movements] Petrograd: I. Fleytmana [in Russian]
} 


\section{2. "An Essay on the Contemporary History of Judaism"} as a Model of Liberal Publicistic Perspective on Reform Problems

An important topic for the editorial board of "Rassvet" was the topic of reform that was evidenced by the fact that these issues were considered by one of the editors of the journal O. I. Georgievsky in a separate historical study called "Essay on the Contemporary History of Judaism". This work was published in March 1860 in the radicaldemocratic journal "Russkoe slovo"17. But a broad response has elicited this study from the southern Jewish population. "Rassvet" provided opportunities to discuss the work on its pages. So, let's turn to the basic foundations of this historical and journalistic work. At the beginning of this fundamental work, the author drew the readers' attention to the peculiarities of the modern historical period. In his opinion, modernity required solving new issues and tasks that arose with unprecedented speed in various spheres of state, public, and religious life. All these changes, in his opinion, were especially relevant and necessary for the Jewish people. He reminded that Jews make up a large part of the population of the Russian Empire, which means that their fate is closely related to the interests of other citizens of the state. It should be noted that the work itself was dedicated to the author, the writer, the founder of Jewish literature in Russian, and the editor of the first Jewish magazine published in Russian Y. A. Rabinovich. In connection with the new tendencies that arose in the solution of the Jewish question in the late $1950 \mathrm{~s}$. O. I. Georgievsky insisted on the need for close attention to the sociopolitical problems of the Jews, both from the state and from the public. In his essay, he carefully analyzed the work of the famous Judaist theorist S. Stern, which was published several years earlier in Germany. In his essay, O. I. Georgievsky not only introduced readers to its content but also expressed his views on reforms. He considered and analyzed the main views contained in this historical essay. Research can be divided into three main parts. In the first part, the author analyzed the historical roots of Judaism. The second part

\footnotetext{
${ }^{17}$ Georgievskiy, A. (1860) Ocherk sovremennoy istorii yudaizma [Essay on the Contemporary History of Judaism] Russkoe slovo - Russian word, 3, 1-58 [in Russian]
} 
deals with the main tendencies of reforming Judaism in Western Europe. And finally, the third part of the study contained an analysis of new trends in the development of Jewish communities in Russia and the necessary changes, according to the author. Considering the historical role of Judaism, O. I. Georgievsky noted that he is grateful for this collection of moral and ethical norms that the Jewish people, despite their very difficult historical periods, managed to preserve in their identity. He began to study the historical roots of Judaism since the Middle Ages. This period he considered the most difficult for the Jews. The author emphasized the great historical significance of Judaism during this difficult period. "The Talmud in these centuries of sorrow was their moral auspices, the stronghold of their national and religious identity, and without it, they would perish among the flood of hatred common to them", he wrote ${ }^{18}$. At the same time, O. I. Georgievsky noted that it was this isolation that virtually shielded the Jewish people from socio-historical progress. By the end of the Middle Ages, under the influence of evolving science and literature, the countries of Western Europe had made a major step forward on the road to tolerance. In countries where Protestantism began to assert itself with the onset of modern times, the Jewish population grew steadily. In the XYII century. Spanish or so-called Portuguese Jews were actively migrating to souther France, to western Germany and, in particular, to the Netherlands. The author noted that these migrants were rich and had an excellent education, which differed significantly from their fellow peers. Because of them, Europe was scattered about Jews as orthodox and ignorant. Thus, the author of the essay understood the centuries-old, strict adherence to the norms of Judaism, due to rigid historical causes. This way allowed the Jews to maintain their national identity. Nevertheless, the author was analyzing the history of the Jewish people in modern times, concluded the possibility and necessity of reforms. The examples in his study were to re-emphasize the reformist potential contained in Judaism. He was convinced that many of the norms of Judaism were obsolete so that

${ }^{18}$ Georgievskiy, A. (1860) Ocherk sovremennoy istorii yudaizma [Essay on the Contemporary History of Judaism] Russkoe slovo - Russian word, 3, 3 [in Russian] 
they could not be governed in the present day. At the same time, the reform process can be directed in such a way that the Jewish law will be preserved, but it will make such changes necessary for the Jewish society that would contribute to historical progress. In the second part of his work, O. I. Georgievsky, while analyzing the historical stages and progress of reforms to resolve the Jewish issue in Western Europe, focused on the specific problems facing the Jewish communities in Russia. This approach, according to the author, would avoid many mistakes by the state during the period of transformation. First of all, he referred to the example of Prussia. In 1750, a "general Jewish privilege" was promulgated in Prussia, which, according to the author, contained many more humiliating provisions. However, because of this document, Jews were able to view Prussia as their homeland and not as a temporary residence place. He wrote, that The successes of European education and philanthropy marked the beginning of the return of Jews to common life and, over time, brought them out of the suffocating sphere of medieval Judaism into the wide field of universal education.

In the historical study, both the positive and the negative aspects of the traditions of Jewish education were considered. Positive phenomena were attributed to the fact that in the eyes of every Jew, even the common man there is no religion without science and there is no teaching without religion. On the other hand, it was noted that in the case of adherents of orthodox Judaism, all doctrines are reduced only to mastering the abstract legal and religious definitions of the Talmud. The author asserted: "Not one, perhaps, a thousand mental gifts have perished among the merciless, premature mental torture, carried out even now and thereby seven tireless and uneducated melamed"19. Thus, the author emphasized that the reform of Judaism should begin with the reform in the field of Jewish education. Studying the reforms in Austria, the author emphasized the fact that the process of emancipation of the Jews in this country was initiated by the government, which could explain the strong resistance to these reforms among the Austrian Jews. This historical fact served as the author's

${ }^{19}$ Georgievskiy, A. (1860) Ocherk sovremennoy istorii yudaizma [Essay on the Contemporary History of Judaism] Russkoe slovo - Russian word, 3, 15 [in Russian] 
further confirmation of the theory that has repeatedly appeared on the pages of "Rassvet". Namely, the decisive role in the cause of any transformation was played by a deep interest in their implementation by the people. A serious argument in favor of this was the example of the history of solving the Jewish question in France. It should be noted that the decree of October 14, 1789, gave French Jews equal rights with Christians. However, according to the author, neither Christians nor Jews in their mass were ready for that: some accepted Jews into their midst, others became full-fledged citizens in Christian society. In this regard, local authorities had to take the most vigorous measures to save Jews from persecution. At the same time, the author focused on several serious positive changes that have occurred recently in the environment of French Jews. "All the Jews of France have mastered the French language, willingly approaching the whole population, not differing in any external features, occupying the highest and highest positions and positions in the state and society," he wrote ${ }^{20}$. Analyzing the historical views of O. I. Georgievsky on the Jewish issue, which he formulated in the Essay on the Contemporary History of Judaism we can state the fact that the author preferred the progressive movement on the part of the state as a response to the changes already made within the Jewish community. This conviction is particularly striking in the third part of his work on the problems of Jews living in the Russian Empire. He acknowledged that for Jews living in Russia, only the dawn of the new age was coming. However, he was convinced that the changes that had taken place in the daily lives of Jewish communities were becoming increasingly apparent. For example, from Western Europe, reformed and updated Jewish schools gradually moved to east. As proof of this, it was presented with facts from the life of the Odessa Jewish community. First of all, he mentioned the activities of Bezalel Stern, through the efforts of whom a Jewish school was opened, which focused not only on the study of the Talmud but also helped the students to acquire secular knowledge, in particular, to

${ }^{20}$ Georgievskiy, A. (1860) Ocherk sovremennoy istorii yudaizma [Essay on the Contemporary History of Judaism] Russkoe slovo - Russian word, 3, 18 [in Russian] 
learn Russian and German. As a result, European education has increasingly penetrated the Jewish environment.

However, O. I. Georgievsky noted that the reform should not only copy the existing European experience but also take into account local conditions. He advocated the idea of compatible learning. In this way, it would be possible to attract not only young people of Jewish nationality to the renovated schools but also to involve children of Christian faith. In these schools, they could study common subjects together. Such examples have already been known in Europe. Also, such a system would allow representatives of different denominations to get to know each other better, giving them even greater chances of coming together and overcoming prejudices. The author praised the examples of Jewish participation in literary activities in Russian. Therefore, the author warmly welcomed the literary work of J. Rabinovich. At the same time, he emphasized that such activities are in no way related to apostasy he supported as author of the essay and the desire of Jewish youth to gain knowledge in high schools and universities. To prove this, the essay contained several important statistics that characterized the situation in the field of Jewish education. Analyzing this data, the author noted that the successes of Jewish education were beyond doubt. He was convinced that universal education would find much more common ground for Christians and Jews, and thus help to eliminate the existing contradictions. Particular attention was paid to Jewish charity work. In this regard, he praised the charity of the Jewish community in Odessa, thanks to which the Talmud-Torah was donated. Also, the Jewish community of Odessa invited Dr. S. Schwabacher, to the position of chief rabbi. He was associated with his work as an author of a favorable outlook for Judaism reform in the Jewish community in Odessa. An important milestone in the dissemination of scientific knowledge and education in the Jewish environment of Russia, O. I. Georgievsky considered the publication of the magazine in Russian. On the one hand, he would acquaint the Russian public and the Russian government with all the peculiarities of the way of life, character, aspirations, views, and interests of the Jews. Upon careful consideration of O. I. Georgievsky's essay, it becomes apparent that the author 
emphasized great importance not only to changes within the Jewish communities but also to a progressive movement for progress that was impossible without a thoughtful policy on the part of the state. In connection with this, the author sharply criticized the existence of a strip of residence in Russia. In his deep conviction, the ban on resettlement throughout Russia adversely affected not only the fate of the Jews but also contradicted the interests of the state. This prohibition, which artificially shielded Jewish communities from the rest of the world, contributed to their further orthodox development.

The author believed that permission to settle everywhere would lead to mass migrations. Only some Jewish families who have embraced European education would dare to do so. For the rest, it would be extremely difficult to take such a step. This would require knowledge of the language, traditions, and customs of your chosen place of residence. The example of Germany, according to the author, eloquently testified that progressive changes in Jewish communities were preceded by a permit for universal residence. A major role in the reform process, the Jewish society's readiness for the planned changes. Assessing the prospects of the emancipation of Jews in Russia, the author of the essay considered it was only a matter of time. "It would be strange in a modern state to alienate thousands and hundreds of thousands of subjects which, either in language, law, customs, crafts or education, do not differ from the rest of the population", he argued ${ }^{21}$. It should be noted that the views presented in the Essay on the Contemporary History of Judaism and the vision of the necessary transformations of Judaism were ambiguous in the Jewish community. It should be emphasized that O. I. Georgievsky's position reflected the sentiment of only a part of the reform-minded, advanced Jewish intelligentsia. It should be noted that both the "Rassvet" magazine and the "Essay on the Modern History of Judaism" found a significant reflection of the idea of Haskalah. This Enlightenment movement originated in the eighteenth century in Europe and was intended to modernize Jewish society. The Haskalay activists paid much attention

${ }^{21}$ Georgievskiy, A. (1860) Ocherk sovremennoy istorii yudaizma [Essay on the Contemporary History of Judaism] Russkoe slovo - Russian word, 3, 18 [in Russian] 
to the idea of providing modern secular education to the Jewish population. Opportunities for closer communication between Jews and other nations. Adoption and perception of common ideals of European culture by Jewish communities. It is no wonder, then, that the process has had its supporters and equally serious critics.

Thus, in the Essay on the Contemporary History of Judaism, the historical roots of Judaism were outlined. For centuries, on the one hand, they have helped to preserve Jewish identity in difficult political conditions, and on the other, in the author's view, have helped to preserve the conservative foundations of Jewish society. Thus, analyzing the reforms carried out in Western Europe aimed at modernizing the Jewish communities and giving equal rights to the Jews, the author outlined the concept of necessary transformations in the fields of education, charity, and social relations. At the same time, the Jewish community itself should have initiated the reforms. This factor would be a valid argument for achieving the overriding goal of abolishing the seatbelt and obtaining equal rights.

\section{CONCLUSIONS}

So, it should be emphasized that in the Odessa periodicals and journalism in the late 50 's - the early ' 60 s of the XIX century the problems associated with the emancipation of the Jews had significant importance. The Odessa Gazette was one of the first periodicals that addressed issues related to the life of the Odessa Jewish community. The pages of " Rassvet" magazine have already been able to formulate a comprehensive program of necessary changes to address the issue of giving political and civil rights to Jews. Much attention was paid to the unity of Jews, especially in the face of interfaith conflict. From the same point of view, the issue of mutual assistance of the Jews and the development of charity were considered. Particular attention was paid to political and social equality issues by journalism. Drawing on numerous examples of leading Western European countries, the publicists have emphasized the positive role that Jews have increasingly played in various areas of public service. Despite the numerous reforms aimed at modernizing the Jewish communities, which referred to the "Essays on the Contemporary History of 
Judaism," liberal journalism emphasized the need to preserve national identity, religious beliefs, urged to develop its culture, preserve its traditions. Thus, on the pages of the liberal Odessa newspapers, the works of publicists formed a solid foundation, which was intended to activate the social activity of the Jewish population. In the opinion of Odessa journalists, an active civic stance on the part of the Jewish communities would help speed up the process of giving Jews equal rights and freedoms.

\section{SUMMARY}

The article discusses the problems faced by Jewish communities in the middle of the 19th century and their reflection in the Odessa liberal press. The regional aspect of the issue has been selected concerning the following factors. First, the Committee on Determining Measures for the Indigenous Conversion of Jews in Russia came into force during this period. That is why the attention of the authorities was drawn to the south of the country because it was a place of residence of a large Jewish population group. Besides, Odessa became one of the leaders of Haskala. At this point, the establishment of national Jewish journalism began, and talented writers, journalists, and publicists merged their forces to reform all areas of the cultural and social life of Jewish communities. Considering the problems of the existence of the Jewish population in the Russian Empire, the activities of M. I. Pirogov cannot be ignored. While serving as the head of the Odessa educational district, he didn't only draw the attention to the periodical press which emphasized the problems of the Jews, but also personally contributed to the discussion of these problems. M. I. Pirogov made a significant contribution to the creation of the national Jewish press, which was published in Russian, he also defended the opening of the magazine "Rassvet" from some authorities. On the pages of this newspaper, during the hard conditions of censorship, journalists were still able to raise the issues of Jewish communities within the country. Issues of inter-confessional conflicts were also discussed in the journal. With the example of Western Europe and the United States, the magazine provided an analysis of state reforms aimed at promoting Jewish rights. This analysis provided 
an opportunity to move on with a discussion on the necessary reforms in the country. Planned step-by-step conversations, initiated by the Jewish society itself, would, in the opinion of the magazine's publishers, create a favorable atmosphere for governmental action aimed at emancipating Jews. The great attention that "Rassvett" has given to reform issues has pushed one of the editors of this edition, O. I. Georgievskiy to the writing of the socio-historical work "Essays on the Contemporary History of Judaism". Without prejudice to Judaism as a religious doctrine, he reasonably argued for the rejection of his most outdated norms. The author of "An Essay on the Contemporary History of Judaism" advocated the joint training of representatives of different denominations, which, in his opinion, would help to eliminate any national prejudices. Thus, the work raised the issue of the elimination of the sediment band, and thus one of the main restrictions on the disappearance of the national character. And, if the "Rassvet" was mainly highlighting the idea of the necessary increase of the social activity of Jews as a pledge of reforms, the "Essay on the Contemporary History of Judaism" considered the elimination of the habitation lane as the first step on the path of reform by the state authorities. Thus, liberal journalists from Odessa contributed fully to the improvement of the cultural and educational level of the Jewish population, upholding the idea of strengthening cultural and historical ties between people. They were deeply convinced that only fruitful cooperation with the state on the one hand, and preservation of national identity on the other, would make a serious step forward in the emancipation of Jews in all European countries.

\section{REFERENCES}

1. Mindlin, A.B. (2005) Imperator Aleksandr II i "evreyskiy vopros" [Emperor Alexander II and the Jewish Question]. Paralleli Parallels, 6, 20-38 [in Russian]

2. Pirogov M. I. (1858) Odesskaya Talmud-Tora [Odessa TalmudTorah]; Odeskiy vestnik - Odessa Herald, 26, 1-2 [in Russian] 
3. Egorov, A. (Konsparov) (1913) Stranitsy iz prozhitogo [Pages from lived]. Odessa: "Slavyanskaya" tipografiya E. Khrisogelos [in Russian]

4. Grebtsova, I. S. (2002) Periodicheskaya pechat' v obshchestvennom razvitii Yuzhnogo stepnogo regiona Rossiyskoy imperii (vtoraya tret' XIXv.) [Periodic press in the social development of the Southern steppe region of the Russian Empire (second third of the $19^{\text {th }}$ century]. Odessa: Astroprint [in Russian]

5. Bogdanovskiy, A., \& Georgievskiy, A. (ed.) (1858) Peredovaya stat'ya [Editorial]. Odesskiy vestnik - Odessa Herald, 119, 1 [in Russian]

6. Bogdanovskiy, A., \& Georgievskiy, A. (ed.) (1859) Novorossiyskiy literaturnyy sbornik [Novorossiysk literary collection]. Odessa: P. Frantsova. [in Russian]

7. Rabinovich, Y. (ed.) (1860) Pis'mo v redaktsiyu "Rassveta" [Letter to the editors of "Rassvet"]. Rassvet - Sunrise, 27, 432 [in Russian]

8. Georgievskiy, A. (1860) Obzor inostrannoy evreyskoy zhurnalistiki [Review of Foreign Jewish Journalism] Rassvet Sunrise, 1, 9-13 [in Russian]

9. Georgievskiy, A. (1860) Obzor inostrannoy evreyskoy zhurnalistiki [Review of Foreign Jewish Journalism] Rassvet Sunrise, 4, 55-57 [in Russian]

10.Georgievskiy, A. (1860) Obzor inostrannoy evreyskoy zhurnalistiki[Review of Foreign Jewish Journalism] Rassvet - Sunrise, 5, 76-77 [in Russian]

11.Georgievskiy, A. (1860) Obzor inostrannoy evreyskoy zhurnalistiki [Review of Foreign Jewish Journalism] Rassvet Sunrise, 10, 156-159 [in Russian]

12.Rabinovich, Y. (ed.) (1860) Peredovaya stat'ya [Editorial] Rassvet-Sunrise, 21, 338-341 [in Russian]

13.Rabinovich, Y. (ed.) (1860) Peredovaya stat'ya [Editorial] Rassvet- Sunrise, 46, 739-742 [in Russian]

14.Tsinberg, S. L. ( 1915) Istoriya evreyskoy pechati v Rossii v svyazi s obshchestvennymi techeniyami [The history of the Jewish 
press in Russia in connection with social movements] Petrograd: I. Fleytmana [in Russian]

15.Georgievskiy, A. (1860) Ocherk sovremennoy istorii yudaizma [Essay on the Contemporary History of Judaism] Russkoe slovo Russian word, 3, 1-58 [in Russian]

\section{Information about the author: \\ Olga Likhachova,}

Candidate of Historical Sciences, Associate Professor,

Associate Professor at the Department of World History and Methodology of Science, South Ukrainian National Pedagogical University named after K. D. Ushinsky 26, Staroportofrankovskaya str., Odessa, 65020, Ukraine ORCID ID: orcid.org/0000-0002-3262-4913 
DOI https://doi.org/10.36059/978-966-397-169-8/47-67

\section{EUROPEAN PRACTICES OF ISSUANCE OF STAMPS: HISTORICAL AND CULTURAL ASPECTS}

\section{Svetlana Oriekhova}

\section{INTRODUCTION}

The postage stamp is a mail stamp or fiscal stamp of a certain value; an evidence of payment of the state postage fee; the sign of the mailings issued by the communication agencies; an artistically designed miniature edition. Postage stamps are also used to promote state achievements in various fields of production, science, culture and sports, etc.

The pictorial content of the postage stamp provides the opportunity to perceive information, which plays an important role in the scientific and cognitive process of state-making activities as well as represents political and economic documents that describe the socio-economic and cultural life of the state as a peculiar means. Accordingly, the history of the postage stamp is presented as a narrative for the visualization of the history and culture of each issuing country, a member of the Universal Postal Union.

While considering national traditions and symbols that are included in the subject line of postage stamps, it is worth to highlight how history and memory have contributed to the formation of characterstate cultural state identification. The artistic postage stamp is not only the subject of collecting and studying of philatelists as an object of art. It is rather a complicated and multifaceted process of comprehension of the artistic and educational space in this context, since it is based on an interdisciplinary general theoretical base and is the object of research of historians, art critics and philosophers.

The phenomenal invention of a method of payment for mail services - the establishment of a postage stamp, has formed "historypolitics-education" triad. For almost two hundred years of the existence, philately has gone beyond admiration and achieved the status of a special historical discipline. 
The subject of philatelic research are postage signs, which include stamps, labels, tag, provisionals, postage grills (calendar and special postmarking of a postage stamps), postmarks, as well as envelopes, postcards and leaflets with these signs printed (postal stationery) or pasted (philatelic cover) and other types of philatelic materials. The subject matter of the study is the history of the postal service of the issuing country. The peculiarities of methodological techniques of the specialized discipline of "philately" are due to the specificity of its sources - carriers of diverse historical information and the uniqueness of the subject of study. According to the subject of study of the history of philately, its main methodological directions include:

- systematization of knowledge about the origin, development, nature and composition of the source base of philatelic history in the world;

- classification of conditions of its operations, internal interaction and external relations;

-development of methodology and methodology of scientific search, study and use of sources from the history of philately.

At the same time, the intensification of national self-identification, a vibrant self-expression of the ethnic component in every national culture, is being intensified.

Therefore, one of the primary tasks is to develop within the diversity of sciences, disciplines, research methods, ideas of clear methodological principles for the study and study of the philatelic area in the context of modern scientific knowledge. The essence of this new concept of history makes it possible to comprehend the vector of the development of the most modern processes in the national art, artistic and creative space, cultural and educational activities.

\section{The evolution of the postage stamp: analysis of thevisual representations in the historical world context}

In the history of mail, the issue of a postage stamp of 1-penny (black) and 2-pence (blue) denominations by the British postal service as well as envelopes of the same denominations and colours marked 1840. The English collectors subsequently called the world's first postage stamp "Penny Black", a small watermark on a small crown, 
the portrait of the Queen of Great Britain, Victoria, is depicted on it ${ }^{1}$. The issue of postage stamps was a direct consequence of the rapid economic development of the most important countries in Europe and, above all, England. The rapid growth of industry caused no less rapid expansion of trade, which, in its turn, led to an increase in mail exchange. A serious obstacle in this direction was the imperfect system of processing mail, disproportionately high postal rates associated with extremely complex calculations. Postal tariffs at that time were set depending on the distance and the number of sheets of which the letter consisted. Full payment for delivery was charged for each sheet of the letter. The minimum tariff in England, for example, was 2 pence. However, depending on the distance and many other factors, sending a letter consisting of only one sheet of paper often cost shilling and a half. These facts were the reason for a member of the English parliament, Samuel Roberts, to issue a pamphlet in which he demanded the establishment of a single rate of 1 penny for all letters, and in 1834, the book dealer and newspaper publisher Charles Knight proposed the issuance of 1-penny envelope for sending newspapers. Both of these proposals were not accepted by the General Post Office. After some time, the Royal Postmaster Rowland Hill returned to the proposals: in his famous leaflet "The Importance and Benefits of Postal Reform" he put forward as the most important task - the establishment of a rate of 1 penny for all letters weighing up to half an ounce (about 14.2 grams). R. Hill believed that the postage should not exceed that amount for simple letters sent within the territory of the United Kingdom, regardless of distance. At the same time, he proposed issuing envelopes, stamped sheets of postal paper and postage stamps for franked letters. This proposal served as the basis for postal reform. The new tariff was specified by the law on January 10, 1840. The cost of sending letters weighing up to $1 / 2$ ounce was set at 1 penny, up to 1 ounce -2 pence and each subsequent full or incomplete ounce - also 2 pence. The maximum weight was set at 16 ounces (approximately

${ }^{1}$ Levitas J. Ya., Basyuk V. (1975) Vse pro marky' [All about brands]. Kiev: Reklama (in Ukrainian). P. 13. 
454 grams $)^{2}$. The drawing on the front side of the envelope obtained by folding the mailing sheet was created by the artist William Mulready who took part in the competition announced by the English Treasury (adopted on May 6, 1840). These envelopes, which have become very rare today, are called "Mulready envelopes"3. Although the first postage stamps appeared in England, other countries used franking notes similar to them much earlier.

Thus, stamped receipts had been in use in Berlin since 1827. In Greece since 1831 official charitable stamps were sold. The Postmaster-General of New South Wales organized the sale of stamped envelopes in 1838. In Sardinia, in 1818, 15-, 25- and 50- centesimo sheets of postal paper were issued with an embossed image of a postman, which corresponded to the cost of private delivery of correspondence to different zones. According to the drawing, these sheets are called "small horses" among the collectors.

At the beginning of the 19th century, there were two methods of collecting postage. In one case, when the sender paid the shipping cost, the letter was called "Paid" or "Franco". If the "Franco" letter was put in the mailbox, the sender should have put there the proper amount of money. In the second case, letters could be sent unpaid; then the postage was paid by the recipient and was called "porto". But all the time there were such cases when letters had to be transported through the several state borders. Each country had its own principles of calculation, its own postal rates. The various tariffs led to the fact that the postal fee for letters addressed abroad, increased disproportionately. The elimination of zones by distance and the convenient franked letters with the usage of postage stamps greatly facilitated the calculation of the amount of postage. Therefore, it is not surprising that the postal administrations of other countries showed a keen interest in the innovation introduced in England. The first one who decided to introduce postage stamps was Zurich cantonal mail

${ }^{2}$ Levitas J. Ya., Basyuk V. (1975) Vse pro marky' [All about brands]. Kiev: Reklama (inUkrainian). P. 16.

3 Grallert V., Grushke V. (1977) Fy'lately'sty'chesky'j slovar' [Philatelic Dictionary]. Moscow: Communicatio. (inRussian). P. 70. 
in Switzerland. In March 1843 they created black colour stamps printed lithographically, and on October 1 of the same year the first postage stamps were issued in the canton of Geneva. The follower of the postal innovation of Switzerland was Brazil. There, the establishment of postage stamps was preceded by the postal reform: letters were distributed by weight category, classification by distance was cancelled; for letters sent by sea mail, a double tariff was established; emigrants' letters sent to their homeland were completely postage free. Thus, it was established mandatory prepayment of postage - the system that most countries do not currently use. Along with the rules for franked letters, Brazilian decrees provided for the payment for stamps using a postmark. Thus, on August 1, 1843, the first postage stamps appeared in Rio de Janeiro, which later received the name "bull eyes" from philatelists. Postmaster Henry Bishop, who in 1661 for the first time used a stamp to fix the route and time (duration) of the mailing, introduced the world's first postal stamp in England ${ }^{4}$.

In subsequent years, franking notes (postage stamps and envelopes, as well as postmarks as a way of paying for the stamps) were actively adopted in many countries of the world. Sometimes these were stamps, such as in Basel (01.07.1845) or on the island of Mauritius (01.10.1847), and sometimes envelopes with a stamp. Today, these stamps are extremely rare: they are rarities in philately and their auction value amounts to tens of millions of dollars.

Periodization of the introduction of postage stamps:

1843 - Cantons of Zurich and Geneva in Switzerland, Brazil;

1847 - USA (5-cent red-brown stamps with the image of Benjamin Franklin and 10-cent black stamps with the image of George Washington);

1849 - France (20-, 40-centime and 1-franc stamps are known under the name "Ceres" with the image of the goddess of agriculture); Belgium (10-, 20-centime denomination, the Epaulet series with a portrait of Leopold I) and Bavaria (received the name "Black unit");

4 Grallert V., Grushke V. (1977) Fy'lately'sty'chesky'j slovar' [Philatelic Dictionary]. Moscow: Communicatio. (inRussian). P. 14. 
1850 - Austria (Austrian territory of Lombardy-Venice, 5-centesimo Queen Isabella II, the inscriptions "correos" (mail) and "franco" (payment), the name of the state was denomination); Spain (image of not indicated); New South Wales and Victoria (first stamps of Australia); Saxony (3-pfennig denomination - "The Sachsen 3 Pfennige red"; Prussia (6-pfennig, 1, 2- and 3-zilbergrosh denominations, image of Friedrich Wilhelm IV) and others;

1851 - Sardinia (a series of three stamps with the profile of King Victor Emmanuel II); Denmark (4-Ricksbankskilling denomination, royal regalia in a laurel wreath); Canada (3-pence stamp "Threepenny Beaver");

1852 - Papal region (the series consisted of eight miniatures of various denominations from $1 / 2$ - to 7 -baiocco. Image of the papal coat of arms - crossed keys of St. Peter and the papal tiara); the Netherlands (nominal value of 5 cents, image of King Willem III, William III, Willem Alexander Paul Frederick Lodewijk), mail Turn and Taksis (the first stamp from the first issue for the North German states was with a value of Silbergroschen);

1853 - Cape of Good Hope (the first stamp of Africa) (1-penny, 4- and 6-pence, 1-shilling denominations, the figure of a woman with naked breasts at the ship's anchor was depicted - an allegory of hope, philatelic name "primitive marks of the Cape colony, the first triangular marks in the world);

1854 - India (they started to use stamps in Sindh province, in the centre of the stamp there was a traditional trademark of the British East India Company);

1857 - Russian Empire (a detailed description is presented below);

1861-1863 - Italy (the first series of 8 stamps of the Kingdom of Italy with from 1-centimesimo to 2-lira nomination were adopted on December 1,1863 . The stamp value in a curly frame was depicted on 1-centezimo miniature, portrait of the king Victor Emanuel II and the inscription "Poste italiane" were depicted on the rest stamps);

1866 - Egypt (text in Arabic and Masri, the outline had oriental ornament);

Honduras (the coat of arms of the country and the name of the state "Correos de Honduras" (post of Honduras) was depicted. There is 
doubt in the philatelist community that these stamps received by mail); Serbia (three miniatures with a portrait of Prince Michael III and the inscription "K. Serbian post" in Serbian);

1868 - Iran (imperforated stamps depicting a heraldic lion were printed in Tehran from those made in Paris, they were used only in Tehran, Qazvin, Zinjan and Tabriz);

1871 - Japan (series of 4 stamps, denominations indicated in mona, two-colour drawing consisted of a pair of dragons facing the centre where hieroglyphs representing the denomination were printed); Hungary (series of six stamps, miniatures with a portrait of Emperor Franz Joseph I and the coat of arms of the Kingdom of Hungary);

1872 - Germany (Deutsche Reichspost was officially established on May 4, 1871, the first stamps of imperial mail was adopted);

1878 - China (image "big dragon", the inscription "CHINA" in Latin and Chinese characters, the denominations on the stamps were indicated in kandarin);

1879 - Bulgaria (stamps of five denominations in French currency from 5 to 80 centimes, image - reproduction of an old Bulgarian symbol, a standing lion);

1984 - Abyssinia (Ethiopia) (on the stamps of four lower denominations, Menelik II was depicted wearing the coronation crown, on the other three stamps of higher denominations there was the image of the heraldic Leo from the tribe of Judah. The name of the country was indicated in Amharic, the denominations of stamps were are from $1 / 4$ to 16 gersh).

Thus, technological progress, the development of foreign relations between the countries of the world increased, as well as the culture of correspondence encompassed wide sections of the country's population, thereby postal service expanded its borders and became an affordable means of communication both within the state and far beyond its borders.

In Russia, the postage stamp appeared much later. However, it was preceded by such events - the first signs of postal payment were introduced by Russian mail in the form of stamped envelopes. On January 1, 1845 in Finland they were used for the whole principality, which was then a part of the Russian Empire; December 1, 1845 - for 
the Metropolitan, St. Petersburg City Post Office and, finally, on December 1, 1848 - for foreign correspondence throughout the country.

The project of introduction of stamped stamps (original name) belonged to the head of issues of mail transportation by train O. P. Charukovsky. Preparation for the introduction of postage stamps in Russia began in 1852. The Russian State Historical Archives in St. Petersburg funds contain letters from the Director of the Postal Department, F. I. Pryanishnykov, to the Prussian Post Director regarding the experience of franked correspondence using postage stamps ${ }^{5}$.

In 1856, trial sketches of stamp stamps were made under the direction of Ya. A. Reichel, head of the printing department of the Securities Procurement Expedition (St. Petersburg), but the samples were not approved. Later, a new drawing of the future Russian rectangular postage stamp was created by F. Kepler, an engraver of Securities Procurement Expedition. In November 1856, the State Council considered the project on the issue of stamps, and a year later in November 1857 the project was approved. The design, the form and the name of the mark were also approved, instead of the "stamped" it was named "postal".

In January 1858, Russia's first postage stamp, with a nominal value of 10 kopecks, was adopted ${ }^{6}$. The first issue of Russian stamps was published in the State Paper Procurement Expedition with a total circulation of 3.0 million copies. One printed sheet contained one hundred units of stamps, without perforation. The stamp had a rectangular shape, an inner oval, in the form of a medallion, blue with a white embossed state emblem of the Russian Empire and postmarks - cross horns. The medallion was surrounded by a mantle crowned with a crown, under the mantle there was an inscription "10 kopecks per an item" (10 kop. za lot), in the corners the

${ }^{5}$ Oriekhova S. (2006) Istorija rozvytku poshtovogho zv'jazku u Donecjkij oblasti XIX-XXI st. [History of postal service development in Donetsk region, XIX - XXI centuries]. (PhD Thesis), Donetsk: DonNU. C. 60.

${ }^{6}$ Russian State Historical Archives in St. Petersburg f. F. 1289, op. 13, spr. 1249. 
denomination of mark "10" was determined with the Arabic numerals. Subsequent issues of the stamps were perforated. Stamps were issued in 10-, 20- and 30- kopeck denominations. For the 60-year period (1857-1917), one hundred and thirty-three varieties of Russian postage stamps were issued, which usually differed in colour and perforation, but the plot remained unchanged. Only three series of stamps had distinct differences: two charities (1905 and 1914 issuance) and one anniversary (1913 issuance $)^{7}$.

Since 1864, postal items sent abroad were paid for by postage stamps. To this end, the Post Office Department issued a circular "On franked foreign correspondence with postage stamps", on the basis of which, in addition to the existing ones, 1-, 3- and 5- kopeck stamps were introduced ${ }^{8}$. In March 1872, the first open, so-called light letters, now known as postcards, went on sale in Russia. The front of the card contained some place intended only for the address, the back side - for the written message itself. From May 1872 there were postcards with stamps printed on them (3-kopeck one - within the city limits, 5-kopeck one - long distance transportation) ${ }^{9}$.

Thus, these transformations have significantly affected the socioeconomic life of the countries of the world. This, in turn, required postal services administrations to further improve their postal services, such as achieving speed and regularity, expanding the network of postal and subsequently postal and telegraph institutions, expanding the range of services and reducing the cost of services, and so on.

The history of the Ukrainian postage stamp is multifaceted: there are many landmark, attractive and poorly researched pages that also deserve review and research. With the proclamation of the Ukrainian People's Republic as an independent state, in the spring of 1918, the first five postage stamps of the UPR were established, the authors of

${ }^{7}$ ZagorskyB., KirzhnerI. (2009) Katalog pochtovykh marok Rossii 1857-1991. Rossii, RSFSR, SSSR: katalog-spravochnik [Catalog of Russian Postage Stamps 1857-1991. Russia, RSFSR, USSR: Directory-Directory]. St. Petersburg: Standard Collection. (in Russian) P. 12-20.

${ }^{8}$ Russian State Historical Archives in St. Petersburg f. F. 1289, op. 23, spr. 300.

${ }^{9}$ Russian State Historical Archives in St. Petersburg f. F. 1275, op. 1, spr. 26. 
which were famous Ukrainian artists Antin Sereda and Georgy Narbut. Miniatures in allegorical form depict national symbols of Ukraine. The cost of the stamps was set in monetary units - "shagi", therefore they were called "stamps-shagivky". The first postage stamps of the Western Ukrainian People's Republic also performed communicative functions. During the short time of its existence, the postage stamps of the UPR and WUPR (1917-1920) have gained popularity among European collectors and have become the object of study and cataloguing. In the USSR, their own Ukrainian postage stamps were not issued, although since 1947 the republic was a member of the Universal Postal Union. After Ukraine's declaration of independence, the production of its own postage stamps began in 1992, which for over a quarter of a century has been the unique postal attribution fund of the country. Annually, starting from 1997, stamps, blocks on the common theme of the regional organization of post administrations of the European countries - Post Europare issued. And in 2001 also the mark "Dialogue of civilizations" was issued, the same in the drawings for all the Member States of the UPU, which had participated in the simultaneous release of such stamps on World Mail Day ${ }^{10}$. It should be noted that Ukraine has been a full member of the UPU since June 1947. This fact is confirmed by the circular of the Director of the Swiss UPU Confederation, Mr. Muri, signed on May 30, 1947, which states the accession of the Ukrainian Soviet Socialist Republic to the Universal Postal Convention. During the XXIUPU Congress in 1994 in Seoul, Ukraine was elected to the Governing Body, which defines the authority of the state in the world community ${ }^{11}$.

Thus, in the process of studying the formation and development of European stamp issuance in the period from XVIII-XXI centuries, it should be noted that government tariff policies facilitated the

10 Kramarenko M. (2011) Ukrayna. Katalog hpochtovikh marok 1866-2010 [Ukraine. Stamp catalog 1866-2010]. Donetsk: "The New World" (in Ukrainian)

11 Oriekhova S. (2017) Ukrayina u svitovomu filatelisty'chnomu prostori [Ukrainein the world philatelic space]. Proceedihg of the Ukrayina $u$ svitovomuistory'chnomu prostori (Ukrayina, Mariupol, April21, 2017) (eds. Balabanov K.), Mariupol: MDU, pp. 278-282. 
establishment of postal items (stamps, envelopes, cards). This led to an increase in postal exchanges, the collection of postal items, and the establishment of the World Postal Union, which facilitated the establishment of international postal arrangements.

\section{The role of the Universal Postal Union in the development of a worldwide philatelic strategy}

Among the communication methods and means of sending and delivering messages, postal service is perhaps the oldest. For centuries, the postal service has developed for the long time. It is inseparable from the origin and formation of terrestrial civilizations, and history and development of postal service have always come along ${ }^{12}$.

Mail promotes the institutionalization of the principles of international communication. Significant milestones in the history of the world mail were the expanding shipment of postal correspondence from one country to another, the growth of transit traffic of international postal items of various types. By the mid-19th century it was high time to establish the legal provisions of international legal relations and maintain simplification of the system of tariffs and mutual calculations. With the formation of the Universal Postal Union, the obstacles that divided the nations for millennia and hindered the process of their rapprochement, were removed.

The World Postal Union was founded on the basis of the GermanAustrian Postal Union, founded in 1850. The imperial royal postal controller Joseph Hecht initiated the first proposal for the development of the "universal European postal law". In his book, which was released in 1749 , he made an attempt to unify the numerous, sharply different tariffs of German post offices. Only a hundred years later, on April 6, 1850, the first treaty was concluded in Berlin, which equalized the rights of various German postal offices and laid the foundation for the German-Austrian postal union. In 1859, the idea of creating an international postal organization was put forward by a Danish official,

12 Oriekhova S. (2006) Istorija rozvytku poshtovogho zv’jazku u Donecjkij oblasti XIX-XXI st. [History of postal service developmentin Donetsk region, XIX - XXI centuries]. (PhD Thesis), Donetsk: DonNU. C. 5. 
Josef Michaelsen. At the initiative of the US General Postmaster Mongomery Blair in 1863, a conference of representatives of the postal administrations of 17 European countries and the USA was held in Paris. Several resolutions were adopted, some principles of the work of the future organization were formulated, but the conference did not have practical results. A few years later, Heinrich von Stefan (since 1870 the Director General of the North German Postal Union) and Eugene Borel (Swiss politician who contributed to the creation of the Swiss Postal Union and the conclusion of the Universal Single Postal Agreement) proposed to establish the Universal Postal Union ${ }^{13}$. In 1873, the postal union of European states was created in Berlin. On September 27, 1874 in Bern (Switzerland), an agreement on the organization of the Universal Postal Union was signed with the participation of Russia ${ }^{14}$.

The Universal Postal Conference was opened with the participation of 38 representatives from 22 countries, and on October 8, the Universal Postal Convention was concluded. Representatives of participating countries, including Austria-Hungary, Belgium, Great Britain, Germany, Italy, Norway, Russia, Serbia, USA, Switzerland and Sweden, signed it. The conference resulted in adoption of the unity of the postal territory, postal rate and balancing of postal charges, on complete freedom and, if possible, free transit. On October 9, the congressional conference proclaimed the creation of the Union Postal Universally (UPU).

The legislatures of the Universal Postal Union called for international postal congresses every five years. The executive body of the union became the International Bureau in Bern. The governments of the participating countries have ratified all decisions of the congress. For the first time, the international body had established uniform rules for sending mail and simplifying international mail exchanges.

${ }^{13}$ Grallert V. (1965) Puteshestvy'e bez vy'z. Kny'ga o pochte y' fy'lately'y' [Travel without visas. A book about mail and philately]. Moscow: Communicatio. (in Russian). P. 68.

${ }^{14}$ Russian State Historical Archives in St. Petersburg f. F. 1289, op. 13, spr. 119. 
Subsequent international congresses took place in different member states: Paris (1878), Lisbon (1885), Washington (1897), Rome (1906), Madrid, where the conference had to be taken in 1913, but it failed because of the international situation ${ }^{15}$. The Congresses improved and simplified the procedure for sending various types of correspondence, reduced tariffs, regulated financial settlements, resolved disputes between member countries of the Universal Postal Union, and accepted new members into the union. Thus, during the Paris Congress, a system of international money orders was introduced. At the Congress in Vienna, all the resolutions of existing international postal agreements were revised. The projects on subscribing to time-based publications at the postal institutions were approved as well as the establishment of the Central Accounts Office, which took charge of transit shipments between states, were adopted (previously those calculations were carried out by sending cash between governments).

Today, the Universal Postal Union is one of the largest international organizations operating under the United Nations auspices. The UPU currently consists of 189 member states. The UPU forms a single postal area for the member states $t$. The legal basis of the Union is a set of legal documents, the main of which is the Charter. General Regulations are the legal ground for the Statute. The supreme governing body of the UPU is the World Postal Congress, which meets once every five years. The governing bodies of the UPU are the Administrative Council and the Postal Operations Council ${ }^{16}$. The UPU is responsible for promoting harmony and communication between nations, using optimized international mail exchange management systems, and supporting the work of the World Philatelic Association.

Its core responsibilities include protecting respect for the cultural and national identity, as well as the ethics of Member States, based on the understanding that the postage stamp is a means of promoting the image of the country as it serves as a travelling ambassador getting around the world.

\footnotetext{
${ }^{15}$ Russian State Historical Archives in St. Petersburg f. F. 1289, op. 2, spr. 1.

${ }^{16}$ Knyazyeva N., Gorelkina S., Ivanov V., Kuzneczova L. Markety'ng poshtovogo zv'yazku [Mail marketing]. Kiev: TOV "Vy'davny'cztvo “Aspekt-Poligraf" (in Ukrainian). P. 39.
} 
Stamp collecting is influenced by many factors. With the reference to the fact that the responsibility for ensuring the success of philately is shared, this is the basis for the philatelic sector and postal administrations to form an association for many years. In the early 1990s, philatelic partners (states) made great efforts to promote dialogue and engagement. States' postal administrations have made a major contribution to the creation of the UPU Contact Committee with the Philatelic Associations. With the acknowledgement of the importance of the association, in 1999 the Beijing Convention authorized the restructuring of this committee into the World Philatelic Development Association (WADP) ${ }^{17}$. Today WADP is a branch of the UPU, which is subordinate to the Postal Operations Council (POC).

It is a strategic forum whose activities provide the postal administrations and their philatelic partners (agents, collectors, brand dealers and specialized media) with the possibility to cooperate, to protect the integrity of postage stamps, as well as to develop and promote philately around the world.

Table 1

Members of the World Philatelic Development Association

\begin{tabular}{|l|c|l|}
\hline Postal administrations & UPU & \multicolumn{1}{|c|}{ The Universal Postal Union } \\
\hline Specialized media & AIJP & $\begin{array}{l}\text { The International Association } \\
\text { of Philatelic Journalists }\end{array}$ \\
\hline $\begin{array}{l}\text { StampCatalogues } \\
\text { and albums }\end{array}$ & ASCAT & $\begin{array}{l}\text { The International Association } \\
\text { of Publishers of Stamp } \\
\text { Catalogues, Albums, and } \\
\text { Philatelic Magazines }\end{array}$ \\
\hline Collectors & FIP & $\begin{array}{l}\text { The Fédération Internationale } \\
\text { de Philatélie }\end{array}$ \\
\hline Stamp Dealer & IFSDA & $\begin{array}{l}\text { International Association } \\
\text { of Stamp Dealer Associations }\end{array}$ \\
\hline $\begin{array}{l}\text { Printing stamps } \\
\text { printers }\end{array}$ & $\begin{array}{l}\text { INTER- } \\
\text { GRAF }\end{array}$ & $\begin{array}{l}\text { International Confederation } \\
\text { for Printing and Allied Industries } \\
\text { (INTERGRAF) }\end{array}$ \\
\hline
\end{tabular}

${ }^{17}$ World Postal Union (1999) Konvenciya Vsesvitn'ogopo shtovogo soyuzu [World Postal Union Convention]. Beijing: World Postal Union. 
The tasks of World Association for the Development of Philately (WADP) are as follows:

- promoting the development of philately and reviving it and collecting stamps as a major hobby;

-capture and support interaction between all key agents in the philatelic sector;

- supporting the implementation of a stable philatelic strategy worldwide.

The general provisions of the UPU provide that only postal administrations issue postage stamps confirming the payment of postal items according to the UPU. The themes and design of the postage stamps correspond to the spirit of the Preamble to the Statute of the UPU and the decisions taken by the Union bodies. The guidelines also require postal administrations to report new issues and exchange stamps to each other through the UPU International Bureau. Another guideline specifies the requirements for postage stamps, country names, denominations, and specifies their size and the use of punching. Article 8 of the UPU Convention specifies all orders of the UPU concerning postage stamps ${ }^{18}$. It describes in particular the activities of the postal administrations concerning the development of the philatelic area, the Code of Philatelic Ethics of the UPU.

The Code of Ethics is a key element in guidance of postal administration according to the question of development and growth of philatelic enthusiasm that raises trust in collecting in the country and the world.

Ukraine has become a full member of the UPU since June 1947. To join the UPU, Ukraine adopted the UPU Charter. As an independent state and a member state of the UPU, Ukraine has been a postal stamp issuer since $1992^{19}$.

\footnotetext{
${ }^{18}$ World Postal Union (2008) Konvenciya Vsesvitn'ogo poshtovog osoyuzu [World Postal Union Convention]. Geneva: World Postal Union.

19 Oriekhova S. (2017) Ukrayina u svitovomu filatelisty'chnomu prostori [Ukrainein the worldp hilatelic space]. Proceedihg of the Ukrayina $u$ svitovomu istory'chnomu prostori (Ukrayina, Mariupol, April21, 2017) (eds. Balabanov K.), Mariupol: MDU, pp. 278-282.
} 
However, the history of philately in Ukraine is inextricably linked to the world of philately. Based on catalogued issuance of postage stamps of Ukraine (1866-2019), a periodization of the history of philately of Ukraine in the context of world development is presented below (Table 2$)^{20}$.

Table 2

\section{The History of Philately}

\begin{tabular}{|c|l|}
\hline $\begin{array}{c}\text { late XVIII s. - } \\
\text { up to 1838 }\end{array}$ & $\begin{array}{l}\text { Collecting fiscal (emblem) stamps and signs that gave the } \\
\text { right to forward correspondence (lettering). The right } \\
\text { specify exemption from payment of postage. Issue of the } \\
\text { first philatelic cover with paid postage. } \\
\text { Before the existence of postage stamps on the territory of } \\
\text { the Carpathian Ukraine (up to 1850), Left Bank Ukraine, } \\
\text { Slobidska Ukraine and Southern Ukraine (up to 1857) }\end{array}$ \\
\hline \multirow{3}{*}{1840} & $\begin{array}{l}\text { Global trend is issue of the first postage stamps and one- } \\
\text { piece items with paid postage for shipment within the } \\
\text { country. }\end{array}$ \\
\hline The $1850 \mathrm{~s}$ & $\begin{array}{l}\text { The establishment of the first catalogues encourages the } \\
\text { collection of postage stamps and philatelic cover. State } \\
\text { stamps of the Russian Empire (since 1857). }\end{array}$ \\
\hline the 1860 s - $1870 \mathrm{~s}$ & $\begin{array}{l}\text { The first exposuring of the collections is organized. } \\
\text { Austrian issues of postage stamps on the territory of the } \\
\text { Carpathian Ukraine (1850-1871), postage stamps of the } \\
\text { Ukrainian districts on the territory of Left Bank Ukraine, } \\
\text { Slobidska Ukraine and Southern Ukraine (1866-1917) }\end{array}$ \\
\hline the 1890 s & $\begin{array}{l}\text { There is establishment of philately (collecting traditional } \\
\text { postage stamps and philatelic cover). State stamps of the } \\
\text { Russian Empire (1857-1917). }\end{array}$ \\
\hline early XX century & $\begin{array}{l}\text { Exposuring of postage stamps is becoming more popular, } \\
\text { especially in Europe. }\end{array}$ \\
\hline \multirow{2}{*}{ the $1910 \mathrm{~s}$} & $\begin{array}{l}\text { There is less interest in collecting philatelic cover as they } \\
\text { are no longer catalogued. It caused difficulties in tracking } \\
\text { official issues of them. }\end{array}$ \\
\hline
\end{tabular}

${ }^{20}$ Oriekhova S. (2019) Filateliya - suchasny'jrux v istory'chnijnauci [Philately - a modern movement in historical science]. Proceedihg of the Modern science movement (Ukrayina, Dnieper, April 4-5, 2019) (eds. Vysotsky O.), Dnieper, SPD "Hunter", pp. 823-827. 
Continuation of Table 2

\begin{tabular}{|c|l|}
\hline & $\begin{array}{l}\text { Proliferation of the use of postcards and creation of } \\
\text { decorative (commemorative) stamps lead to the } \\
\text { emergence of maximophilia (collecting and studying of } \\
\text { the maximum cards). These are postcards with the } \\
\text { appropriate stamp of special redemption. The main factor } \\
\text { is that all the components, the card itself and postage } \\
\text { stamp should be consistent with each other). This branch } \\
\text { of philately is popular in France, Netherlands, Belgium, } \\
\text { Poland, Romania, USSR and Ukraine. } \\
\text { the 1910s s }\end{array}$ \\
\hline \multirow{1}{*}{ Czechoslovak issuanceon the territory of the Carpathian } \\
Ukraine (1918-1939)
\end{tabular}


Completion of Table 2

\begin{tabular}{|c|l|}
\hline the $1980 \mathrm{~s}$ & $\begin{array}{l}\text { Contemporary competition categories are being } \\
\text { developed. The particular growth of philately in Asia }\end{array}$ \\
\hline \multirow{2}{*}{ the $1990 \mathrm{~s}$} & $\begin{array}{l}\text { The establishment of two new categories of philately: } \\
\text { emblem stamps and experimental social philately. Stamp } \\
\text { exposuringis spreadwith the use of asingle frame. FIP is } \\
\text { expanding, and worldwide exhibitions are becoming more } \\
\text { and more numerous. }\end{array}$ \\
\hline $\begin{array}{l}\text { The late } 1990 \mathrm{~s}- \\
\text { present moment }\end{array}$ & $\begin{array}{l}\text { The formation of the WPDA (World Philatelic } \\
\text { Development Association) as a new means for } \\
\text { strengthening philately. } \\
\text { State issuance of independent Ukraine }\end{array}$ \\
\hline
\end{tabular}

Therefore, postage stamps are the means of reflecting the country's most valuable heritage and cultural perspectives around the world. The condition and development of philately demonstrates the level of the civilization of the society.

\section{CONCLUSIONS}

Comprehensive study of the sources and literature leads to the conclusion that the genesis of state identification, with the assistance of stamp issuance, is a relevant topic. Thus the choice of the object of study - postage stamps of the first half of the XIX century - beginning of the XXI century as sources of historical memory - is a major element of the scientific novelty. Based on the principles of historical science, such as historicism, objectivity, dialectical principle, with the use of complex, chronological and statistical methods, an attempt to perform a comprehensive analysis of the processes of issue, adopt of postage stamps of the leading states of the world, which are States Parties to the World postal union, is made. In the process of the research of the stated purpose, the following conclusions can be stated.

The issue of postage stamps has been a particularly progressive phenomenon in public administration and the economy, and it has acquired artistic and cultural significance in the world history of philately. Over time, the postage stamp has gone from the direct obligation of the postal administration to the sender, to the formation 
of a source of historical memory and worldview. The modern functions of the postage stamp are:

- economic - the cost of postal services indicated on the mark is the economic component of the state;

- monetary - monetary functions of postage stamps;

- formation of the monetary system of the state;

- attributive - symbols of state identification are depicted on it coat of arms, national currency which contain information about the country as a political statement of state sovereignty;

-advertisement and information - as a method of stimulating interest to the problems of a social nature, the world, charity, etc.;

- collectible - it has both intrinsic and actual value, which can be very different from its postal value. This function is a direct consequence of the development of philately as a hobby spread worldwide;

- cultural - as an art miniature, containing decorative elements and dedicated to a specific subject.

The postage stamp promotes the historical and cultural heritage of the state and it is an effective carrier of its axiological code.

\section{SUMMARY}

Thus, the postage stamp is not just an art miniature through which we look at the past historical reality. It is the most convenient matrix for mastering the ability to relate history as historiographical text with a narrative representation of the past.

The postage stamp is not only a form of payment for services, but also a visualization of the history and culture of each state. Such a miniature thing as the postage stamp is informative. It serves as a marker of events, captures and engraves them on the pages of historical and cultural memory. Without historical memory, each society's history cannot be reproduced. It is an inheritance of the past experience, and it exists in the form of the historical consciousness of the people, embodied in appropriate cultural forms.

Postage stamps, as an element of statehood, represent political and economic documents, which in a peculiar way fixed the socioeconomic and cultural life of the states and formed the basis of modern stamp issuance. 


\section{REFERENCES}

1. Grallert V. (1965) Puteshestvy'e bez vy'z. Kny'ga o pochte y' fy'lately'y'[Travel without visas. A book about mail and philately]. Moscow: Communicatio. (in Russian)

2. Grallert V., Grushke V. (1977) Fy'lately'sty'chesky'j slovar' [Philatelic Dictionary]. Moscow: Communicatio. (in Russian)

3. Knyazyeva N., Gorelkina S., Ivanov V., Kuzneczova L. Markety'ng poshtovogo zv'yazku [Mail marketing]. Kiev: TOV "Vy'davny'cztvo “Aspekt-Poligraf" (in Ukrainian)

4. Kramarenko M. (2011) Ukrayna. Katalog hpochtovikh marok 1866-2010 [Ukraine. Stampcatalog 1866-2010]. Donetsk: "TheNewWorld" (in Ukrainian)

5. Levitas J. Ya., Basyuk V. (1975) Vse pro marky' [All about brands]. Kiev: Reklama (in Ukrainian)

6. Oriekhova S. (2006) Istorija rozvytku poshtovogho zv'jazku u Donecjkij oblasti XIX-XXI st. [History of postal service developmentin Donetsk region, XIX - XXI centuries]. (PhD Thesis), Donetsk: DonNU.

7. Oriekhova S. (2019) Filateliya - suchasny'jrux v istory'chnijnauci [Philately - a modern movement in historical science]. Proceedihg of the Modern science movement (Ukrayina, Dnieper, April 4-5, 2019) (eds. Vysotsky O.), Dnieper, SPD "Hunter", pp. 823-827.

8. Oriekhova S. (2017) Ukrayina u svitovomu filatelisty'chnomu prostori [Ukrainein the worldp hilatelicspace]. Proceedihg of the Ukrayina u svitovomu istory'chnomu prostori (Ukrayina, Mariupol, April 21, 2017) (eds. Balabanov K.), Mariupol: MDU, pp. 278-282.

9. Russian State Historical Archives in St. Petersburg f. F. 1275, op. 1, spr. 26.

10.Russian State Historical Archives in St. Petersburg f. F. 1289, op. 2 , spr. 1.

11.Russian State Historical Archives in St. Petersburg f. F. 1289, op. 13, spr. 119.

12.Russian State Historical Archives in St. Petersburg f. F. 1289, op. 23 , spr. 300 . 
13.World Postal Union (1999) Konvenciya Vsesvitn'ogo poshtovogo soyuzu [World Postal Union Convention]. Beijing: World Postal Union

14.World Postal Union (2008) Konvenciya Vsesvitn'ogo poshtovogo soyuzu [World Postal Union Convention]. Geneva: World Postal Union

15.Zagorsky B., Kirzhner I. (2009) Katalog pochtovykh marokRossii 1857-1991. Rossii, RSFSR, SSSR: katalog-spravochnik [Catalog of Russian Postage Stamps 1857-1991. Russia, RSFSR, USSR: Directory-Directory]. St. Petersburg: Standard Collection. (in Russian)

\section{Information about the author: Svetlana Oriekhova,}

$\mathrm{PhD}$ in History, Associate Professor, Doctoral Student at the Department of Historical Disciplines, Associate Professor at the Department of Cultural Studies and Information Activity, Mariupol State University 12, Budivelnykiv Ave, Mariupol, 87500, Ukraine ORCID ID: orcid.org/0000-0001-9303-4469 


\section{MUSEOLOGY AND MONUMENT PROTECTION IN THE DISCOURSE OF FRENCH NATIONAL IDENTITY}

\section{Oleksii Prysiazhniuk}

\section{INTRODUCTION}

Even in the Renaissance, French kings and aristocrats began to collect ancient antiquities. For example, King Henry II received, as a gift from Pope Paul IV, in addition to bronze copies of famous antique statues, the statue "Diana with a doe" with a hint of his metressa Diana de Poitiers. Later, King Henry IV ordered the Antique Hall in the Louvre to be decorated for this statue. King Louis XIV sailed through "Germanicus" and "Jason" from Montalto's villa to decorate Versailles. However, ancient sculptures and artifacts were scattered, serving only as decoration of the royal palaces: Fontainebleau, SaintCloud, Versailles. The city palaces of the Louvre and Tuileries, of course, contained a considerable number of ancient statues, the Cardinal's Palace (Palais Royal) and the Montmorency Palace competed with them. Interest, however, was caused only by ancient monuments and this entire period can be classified as a stage of "collecting". In general, in France, interest in collecting arises in parallel with similar processes in other European countries and quickly, by the beginning of the 16th century, became a noticeable phenomenon in the life of French society. Collecting collections turns into a phenomenon that covers literally all segments of the population. Belonging to the elite does not mean the obligatory presence of a collection, but the collection itself allows even a non-ordinary person to be accepted into the circle of amateur favorites.

During this period, collection reached its special peak in the 16th18th centuries, when even a special name appeared for collections the cabinet. The composition of the cabinets was determined not only by the degree of wealth and education of their owners, but also by general trends in the development of this phenomenon in France and in Europe. Initially, the cabinets fully met the Renaissance idea of the 
possibility of imitating nature and its knowledge on the basis of a specially created microworld. The composition of the cabinets exhausts the composition of the universe, objects should have been concentrated here, characterizing all the processes taking place in the world.

The level of development of science did not always allow compiling collections on a truly scientific basis. However, the XVII century - the first century of science in the modern sense of this concept - has brought significant changes both in the person's knowledge of the world and in the presentation of this world in classrooms.

At the end of the XVII - XVIII centuries, collections became more specialized in profile, more and more often they included disciplines of the natural science cycle. This process of changing the topic of classrooms was reflected in its own way by the famous "Encyclopedia, or Explanatory Dictionary of Sciences, Arts and Crafts" - the term "cabinet" has only a few lines in it, while an extensive article is devoted to the study of natural history, describing in detail the composition of such a cabinet ${ }^{1}$.

In the 18th century, shifts of a different nature also took place many museum features began to take shape within individual collections. First of all, we mean the design of the principle of accessibility of collections for the public, based on the ideas of the Enlightenment. These representations imply the educational purpose of collections of exemplary works for artists (as role models) and for amateurs (as objects of study). That is why in the "Encyclopedia, or Explanatory Dictionary of Sciences, Arts and Crafts", the creation of the museum was associated with the opening of the royal collection, which included recognized masterpieces of European art. Many collections are open to visitors in the 18th century. These are meetings at drawing academies and schools, private rooms, a royal office, open for visits at the Luxembourg Palace in 1750-1779. However - and this is one of the features of the development of museum business

\footnotetext{
${ }^{1}$ Kuklinova I. A. (2001) Muzei Frantsii XIV - XIX vekov [Museums of France of the XIV - XIX centuries]. St. Petersburg: SPbGUKI. P. 104.
} 
in France - the museum based on the royal cabinet was not opened until the era of the French Revolution, although in the XVIII century there was an active process of creating museums on the basis of royal and princely collections. The formation of museum features in the framework of cabinets during this period is also expressed in posing questions of the significance of objects as historical sources. It was in the 18th century that the first attempts to perpetuate local ancient and modern history in the collections of Arles, Dijon, Toulouse were made. For the first time, the restoration of monuments of the past is being addressed and methods for organizing the exposition are being developed.

Thus, the idea of museums in France was formed throughout the eighteenth century, and the French Revolution was the impetus for the creation in France of the first European network of museums.

\section{Formation of the legislative framework}

The legislative protection of monuments and its cultural heritage in France began in the years of the revolution. The French revolutionary government, by decree of the National Constituent Assembly of 1790, banned the destruction of immovable and movable works of art in the former royal estates, buildings and apartments of emigrants.

"Decree of the Constituent Assembly on public education, on the protection of buildings that have become national property, as well as monuments, storage facilities, libraries, etc., located in Paris on October 13-19, 1790.

The National Assembly decided:

1. That it will deal with educational issues only after the Constitutional Committee, to which it has entrusted the broadest powers in this area, presents its opinion on this part of the constitution.

2. So that the learning process does not stop, the Assembly will ask the King to order the resumption of classes at various public schools this year, as usual, without changing, however, the requirements of the decree on the clergy of the clergy regarding seminaries.

3. The meeting instructs the directories of the departments to collect information on the state of the monuments, churches and 
buildings located on their territory, which have become national property, and by all means at their disposal to protect them. The collected information will be transferred to the Committee on Property Alienation.

4. The meeting instructs the municipality of Paris to show the same care for the numerous monuments of the same kind existing in this city, for the storage of charters, documents, papers and libraries. In order for oversight to be competent, the municipality must cooperate with elected members of various Academies".2.

However, two years later, the National Assembly, which took the reins of government and legislative initiative, allows and even prescribes the destruction of monuments that can remind of feudalism, and the destruction of everything that could revive the memories of the despotism of the royal power.

"Decree of the Legislative Assembly on the destruction of monuments evoking feudalism on August 14, 1792.

The National Assembly believes that the sacred principles of freedom and equality do not allow preserving the monuments erected in the glory of pride, prejudice and tyranny before the eyes of the French people.

The Assembly believes that, cast over the cannons, the bronze of these monuments will usefully serve the cause of protecting the homeland, and decrees the adoption of immediate measures.

By deciding on immediate action, the Assembly decrees the following:

Art. 1. All statues, bas-reliefs, inscriptions and other monuments made in bronze or in any other material, erected in public squares, in temples, gardens, parks and grounds, in buildings belonging to the nation, and even in those that were left in possession of the King, - all these monuments should be removed by the efforts of representatives of the communes, who will temporarily monitor their safety.

Art. 2. Representatives of the Commune of Paris under the supervision of the Minister of the Interior, two members of the

${ }^{2}$ Dokumenty istorii Velikoy frantsuzskoy revolyutsii (1990) [Documents of the history of the Great French Revolution]. T. 1. Moscow: MGU. P. 484-485. 
commission of armaments and two members of the commission of monuments must immediately transfer to the instrument all the items listed in Art. 1 and located in the city of Paris.

Art. 3. All sorts of monuments left over from feudalism and still located in churches, other public places, and even on the facades of private buildings, should be immediately destroyed by communes.

Art. 4. The Commission of Monuments is specifically instructed to monitor the preservation of those objects that are primarily of artistic value, and submit to the Legislative Corps a list of these objects for approval.

Art. 5. The Arms Commission must immediately submit a draft decree, according to which metal from monuments located within the borders of each commune of France, will usefully serve the cause of its protection"3.

A year later, the National Convention decides on the creation of the Museum of the Republic and the collection under its roof of all the most valuable bright works of art. "The decree on the organization of the museum in the premises of the Louvre (according to the report of A.-F. Serjan) July 27, 1793.

According to the reports of the committees of public education and monuments, the National Convention decides:

Art. 1. The Minister of the Interior will give the necessary orders to open the Museum of the Republic on 10 August this year in the gallery connecting the Louvre with the Palais Nacional.

Art. 2. The Minister must order that, under the supervision of Commissars for Monuments, paintings, statues, vases, valuable furniture, marble articles located in the premises of the monastery of small Augustinians, in former royal palaces, in other public buildings and national repositories, with the exception of those items that are currently stored in the castle of Versailles, in parks, in both Trianons and are protected in their department by special decree.

Art. 3. The minister must also order the transfer to the museum of antique paintings, statues and busts located in all former royal palaces,

${ }^{3}$ Dokumenty istorii Velikoy frantsuzskoy revolyutsii (1990) [Documents of the history of the Great French Revolution]. T. 1. Moscow: MGU. Pp. 484-485. 
in castles, gardens and parks owned by emigrants and in other national possessions",

The preparation of the decrees of the Convention for the Protection of Monuments and the organization of the Museum of the Republic was directed by Jacques-Louis David. In July 1793, he made a report at the Museum Vault Convention, where he spoke about general principles and the practical program of museum work. David said: "The museum is not at all a useless collection of luxury goods and vanity, serving only to satisfy curiosity. It is necessary for the museum to become a school of great importance... we need to reveal all the wealth in front of the life-giving eye of the people...",

For the first time for the general public, the doors of the museum opened on August 10, 1793.

Unfortunately, countless artistic treasures have perished as victims of blind fanaticism and a wild passion for destruction in the storms of the French Revolution. The revolutionary government, unable to create and consistently carry out the planned events, contributed little to the preservation of the huge cultural heritage from church buildings and palaces, which passed to it on the basis of the laws of secularization and emigration. Many decades passed, while freedom-loving Frenchmen stopped using medieval monuments of building art for barracks. So, for example, the papal palace in Avignon only in 1906 was freed from the functions of the barracks and carried out restoration.

A somewhat peculiar "merit" of creating a single new center for the storage of ancient heritage in France belongs to Napoleon Bonaparte. Following the example of Alexander the Great and combining the Egyptian expedition with a scientific expedition, he returned to the much less laudable custom of the Roman commanders, who used to plunder conquered countries and take art treasures stolen from them, to Rome. This example was portrayed in the imagination of a young

${ }^{4}$ Dokumenty istorii Velikoy frantsuzskoy revolyutsii (1990) [Documents of the history of the Great French Revolution]. T. 1. Moscow: MGU. Pp. 484-485.

${ }^{5}$ David Zh.-L. (1933) Rechi i pis'ma zhivopistsa Lui Davida [Speeches and Letters by the Painter Louis David]. Moscow; Leningrad: Isogiz. P. 186. 
winner back in 1796, when on June 23 he included paragraph VIII in the armistice in Bologna: "The pope will deliver to the French Republic a hundred paintings, busts, vases or statues of the choice of commissioners to be sent to France, among which will be a bronze bust of Junius Brutus and a marble bust of Mark Brutus, statues from the Capitol and five hundred manuscripts of the choice of the mentioned commissioners" ${ }^{\prime}$. A special reference to the busts of Caesar's killers is characteristic of the Republican. The pope vainly resisted, but this same cruel condition was included in the February 1797 treaty of Tolentino. Among the antique objects, the choice fell on the famous masterpieces of the Belvedere and its hall of muses. The Capitol has lost about a dozen of its best statues, among them the statues of the "Dying Gaul" and "The Boy Removing the Splinter". However, this was not limited to this: under more or less transparent pretexts, private collections were also included - a collection of the Duke of Braska, a relative of the pope, and mainly a rich collection of Cardinal Albani's villa. With revolutionary speed, all the antique artifacts stored in them were confiscated by the French and 517 items packed in 288 boxes were waiting on the Tiber for departure to Paris.

In November 1801, the 18th Brumaire of the year IX, just two years before the coup, the Central Museum was opened in the Louvre, which contained 117 monuments. About two years before this event, Ennio Quirino Visconti, who was briefly one of the five consuls of the Roman Republic, moved to Paris. For almost two decades, his scientific name has given brilliance to French museums and French archeology in general. It was he who compiled the first catalogs of the rapidly growing new museum. But the soul of the whole affair in this case, as in the Egyptian expedition, was Dominic Vivan Denon. He accompanied the army and chose works of art to be taken away. Florence was to give its Venus to the Medici, Venice of its four bronze horses from the church of St. Mark, Mantua, his famous busts of Euripides and Virgil, Verona of his Augustus Bevilacqua, Modena and

6 Mikhaelis A. (1913) Khudozhestvenno-Arkheologicheskie otkrytiya za 100 let [Artistic and archaeological discoveries for 100 years]. Moscow: Izdanie Imperatorskogo Moskovskogo Arkheologicheskogo Instituta Imeni Imperatora Nikolaya II. P. 23. 
Turin other objects. As it once was during the conversion of the Belvedere into the Pioclementine Museum, so now the number of antique halls grew in the Louvre ${ }^{7}$.

In 1806, it included the entire collection of antique objects of the Borghese, which Napoleon bought from his son-in-law Camillo Borghese. Soon, booty from Germany also joined: a praying boy from Berlin accompanying Victoria from the Brandenburg Gate, Athena from Kassel, the imaginary sarcophagus of Charlemagne from the cathedral in Aachen and other works, from 20 to 30 in total. In Vienna, D. Denon from 1809 the antique cabinet chose 24 subjects, among which only the alleged Ephesian sarcophagus with amazons was valuable; the gems of the imperial house were taken to Hungary on time.

The catalogs that often appeared in new editions made it possible to judge the expansion of the museum and its enrichment with selected art monuments. In 1815, the number of storage numbers reached 384 . Free access to the public, the creation of a workshop for making casts according to the originals of the museum, the preparation and publication of large publications with engravings - all this contributed to the increase in the benefits and fame of the Napoleon Museum and drowned the voices of those who put the museum in reproach is the way in which he mainly owed his origin ${ }^{8}$.

The collection of antique objects of the Napoleon Museum was entirely Roman in character. This included the most outstanding monuments of the Roman congregations, with the exception of the collection of Ludovisi; however, at the same time, there was not the fullness of the impression that Rome gave in its general antique character. The fact that the museum lacked the characteristic treasures of Naples deprived him of the advantage over Rome that he would

7 Zhebelev S. A. (1923) Vvedenie v arkheologiyu. Chast' II. Teoriya i praktika arkheologicheskogo znaniya [Introduction to archeology. Part II. Theory and practice of archaeological knowledge]. Petrograd: Nauka i shkola. Pp. 80-81.

${ }^{8}$ Mikhaelis A. (1913) Khudozhestvenno-Arkheologicheskie otkrytiya za 100 let [Artistic and archaeological discoveries for 100 years]. Moscow: Izdanie Imperatorskogo Moskovskogo Arkheologicheskogo Instituta Imeni Imperatora Nikolaya II. P. 25. 
have possessed those paintings and bronzes. The classical periods of Greek art were nevertheless presented in many more or less good copies, the Hellenistic era, and partly the Roman art in such beautiful originals that it becomes clear to E. Q. Visconti's view: antique art from Phidias to Hadrian seemed to be kept at the same height. It was a bold, albeit absurd attempt to replace the view of I. Winkelmann and his followers with another. The main classical idea of I. Winkelman, as you know, can be reduced to the thesis: art arises, develops and fades away in connection with the development of society. The great name of E. Q. Visconti obscured the historical absurdity, which consisted of such a view: six hundred years, full of the biggest changes in the lives of peoples, changes in geographical centers, changes in all politics and culture, but at the same time art is all at the same height, as if soaring above the clouds!

The Napoleon Museum was also the place of education of the then archaeologists. For them, E. Q. Visconti, the court archaeologist of Napoleon, was an indisputable authority, almost an oracle. In Germany, the forerunner of a similar anti-historical teaching was Friedrich Tiersch, who studied antique objects in Paris at that time.

With the fall of Napoleon in 1815, his ambitious creation collapsed. It was perfectly true that the one taken away by virtue of military law, was now returned to the previous owners in military law. Cardinal Secretary of State Consalvi was the representative of the interests of Rome. Wilhelm von Humboldt and the Duke of Wellington successfully tried to break the understandable resistance of the French commissars, mainly D. Denon. His property was returned to the Vatican almost entirely. The fact that the Tiber statue remained in Paris, while its twin statue of the Nile alone returned to the shores of the Tiber, was the result of petty court intrigue. Officially, Pope Pius VII presented the statue of the Tiber restored to the throne of Louis XVIII.

However, return shipping costs were so great that the papal government could only cover them with significant assistance from England. For the same reason, the heirs of Cardinal Albany were satisfied with the return of only four works from the stolen seventy; the rest were auctioned off in Paris and for the most part either returned to 
the Louvre or ended up in Munich Glyptothek. In the Capitol Museum, a special hall was reserved for the returning marbles, where they were grouped around the "Dying Gaul". Only the Borghese collection, as bought, remained in Paris and served as the core of the Louvre collection. The first catalog of this collection, the last work of E. Q. Visconti, published in 1817.

The Napoleon Museum was the last magnificent example of a collection of antiquities in the style of classicism. This museum is at the same time the crown and the end of the whole long revolutionary period in the history of France.

In 1810, a circular was sent out by the Minister of the Interior, Count de Montivalie, according to which the prefects were ordered to collect information about castles, abbeys (monasteries) and tombs that existed and still exist in the territory of their departments. Count Alexander the Labord, author of the work "Monuments of France, classified chronologically and examined in relation to historical facts and the study of art", the first volume of which was published in 1816, took part in its development.

It should also be noted that the entire Napoleonic Civil Code of 1804 had a huge impact on the entire subsequent cultural heritage protection system in France. He laid the foundations for the legislative protection of private property in France, denoting it, however, in article 552 very broadly: "The right of ownership of land extends to the surface and its bowels". In addition, "... on the surface of the earth, the owner can make plantings and constructions as he pleases", as well as "in the bowels of the earth he can undertake all kinds of constructions and excavations as he pleases, and extract from these excavations all the works that they can deliver, subject to the restrictions arising from laws and regulations..."

9 Kodeks Napoleona (1877) [Codex of Napoleon]. Sobranie grazhdanskikh zakonov guberniy Tsarstva Pol'skogo [Collection of Civil Laws of the Provinces of the Kingdom of Poland]. Pp. 159-160.

${ }^{10}$ Kodeks Napoleona (1877) [Codex of Napoleon]. Sobranie grazhdanskikh zakonov guberniy Tsarstva Pol'skogo [Collection of Civil Laws of the Provinces of the Kingdom of Poland]. Pp. 159-160. 
The Code also contains a very broad definition of the concept of "treasure" in Article 716: "The right of ownership of a treasure belongs to those who find it in their own estate; if the treasure is found in a strange estate, then one half belongs to the one who found it, and the other to the owner"11.

Article 552 of the Code defined the French national mentality and made it impossible for the state to assume full-fledged functions for the protection of monuments. Subsequent attempts to introduce state accounting and control of monuments, especially those that were privately owned, were perceived as a gross violation of the spirit of the Civil Code and the blood-fought traditions of French freedom ${ }^{12}$.

\section{Comprehension of the national past and design Basics of Monument Protection}

In the second quarter of the 19th century, the crisis of the value system experienced by France and the French, connected with the French revolution and subsequent events, was gradually resolved in a difficult way from idealizing the ancient past to understanding the national past ${ }^{13}$. At this time, romanticism, a powerful ideological and artistic movement, was a widespread reaction to classicism and the entire Enlightenment. An important feature of romanticism was the socalled "passionist reflection", expressed in the fascination with antiquity, its poetization, interest in folk life and folk literature, which thereby prompted a deep study of their national past. In addition, interest in "their" history and "their" monuments mainly religious, the

11 Kodeks Napoleona (1877) [Codex of Napoleon]. Sobranie grazhdanskikh zakonov guberniy Tsarstva Pol'skogo [Collection of Civil Laws of the Provinces of the Kingdom of Poland]. Pp. 159-160.

${ }^{12}$ Malyshev O. O. (2015) Arkheologhichne pravo Franciji: gheneza ta suchasnyj stan [Archeological law of France: genesis and current state]. Chasopys Kyjivsjkogho universytetu prava [Journal of the Kyiv University of Law]. P. 33-37; Malyshev O. O. (2018) Romansjka ta ghermansjka tradyciji arkheologhichnogho prava: sproba uzaghaljnennja [Romanesque and Germanic traditions of archaeological law: an attempt to generalize]. Pravova derzhava [Constitutional state]. № 29. P. 476-485.

${ }^{13}$ Lebedev G. S. (1992) Istoriya otechestvennoy arkheologii [History of Russian Archeology]. St. Petersburg: SPbGU. P. 69. 
organization of their protection and the development of restoration as an independent architectural movement were largely determined by France's internal political problems associated with a radical change in the socio-political face of society itself ${ }^{14}$.

The era of restoration (1815-1830) also shows examples of gross vandalism and unforgivable indifference of the government, so that Charles de Montalamber in 1830 could complain that over 15 years of the existence of the kingdom more monuments were destroyed in every department of France than during the whole revolutionary and imperial periods.

The government did not prevent privately owned buildings from being destroyed or converted into factories and workshops. It itself used monuments of church and secular architecture, like Mont SaintMichel and the papal palace in Avignon, for military purposes. Such people as Victor Hugo, Prosper Merimet, Charles de Montalamber, Jean-Baptiste Lasso, Eugene Emmanuel Viollet-le-Duc, combined with the efforts of learned societies and the French clergy not only among educated people, but also among the general public of the French population keen interest in monuments of past years. Victor Hugo's novel "Notre Dame de Paris" (1830) sounded a hymn to the glory of medieval architecture and a call to preserve its heritage. Initially, the cathedral, which was bred in the novel, became a subject of general attention. In the future, it was usually not about the construction of new buildings, but about the restoration of the masterpieces of the French Middle Ages, be it Saint Michel, Mont Saint Michel, the grand abbey in Vezle, the ancient fortifications of Carcassonne or the mountain castle of Roktaiad. The tireless Eugene Emmanuel Violletle-Duc had a hand in the implementation of almost all restoration projects, striving to bring even unfinished buildings in the Middle Ages to the last degree of completion.

${ }^{14}$ Rytsarev K. V. (1995) Nekotorye tendentsii v zapadnoevropeyskoy arkhitekturnoy restavratsii XIX veka [Some trends in the West European architectural restoration of the XIX century]. Restavratsiya i arkhitekturnaya arkheologiya: Novye materialy i issledovaniya [Restoration and Architectural Archeology: New Materials and Research]. Moscow. № 2. Pp. 4-5. 
Based on public opinion, interested in the development of history and art, the French government since the beginning of the thirties has been taking a number of measures aimed at protecting monuments.

The preservation of ancient monuments was institutionalized during the July monarchy, which is often defined as the "Guizot moment", named after the French historian and prominent politician Francois Guizot, who served as Minister of the Interior from August to November 1830 and Minister of Education from November 1832 to April 1837. For several years, from 1830 to 1837 , on his initiative, the main institutions of this centralized state system were created: General Inspectorate of Historical Monuments (1830), General in the history of France (1833), the Committee of historical and scientific works (1834), the Commission of historical monuments (1837). They were the organizational embodiment of the policies pursued by King Louis Philippe and François Guizot.

F. Guizot marked his coming to power with the reforms that he had previously proclaimed as a historian. He was worried about the search for foundations for national unity, the legitimization of the third estate, the demands put forward by new national history. He developed and implemented a program for the historical education of French society. "This is a serious disease of the nation," F. Guizot said, "to neglect the past and forget it"15. It was logical that the government of 1830, like the government of the First Empire, sought in respect of the past, in the cult of ancient France, guarantees of stability that were absent during their establishment. In the past, the medieval era was especially distinguished, when "the unity of society was based on the union of the monarchy with the third estate" ${ }^{16}$. National reconciliation was facilitated by the Catholic movement. In his return to beliefs, F. Guizot saw the benefits of maintaining social order and considered religion as

${ }^{15}$ Rytsarev K. V. (1995) Nekotorye tendentsii v zapadnoevropeyskoy arkhitekturnoy restavratsii XIX veka [Some trends in the West European architectural restoration of the XIX century]. Restavratsiya i arkhitekturnaya arkheologiya: Novye materialy i issledovaniya [Restoration and Architectural Archeology: New Materials and Research]. Moscow. № 2. P. 14.

${ }^{16}$ Bazen Zh. (1994) Istoriya istorii iskusstv: Ot Vazari do nashikh dney [History of Art History: From Vasari to the Present]. Moscow: Progress-Kul'tura. P. 217. 
a means of dispelling the moral suffering of the lower classes. This religious revival, which regarded the Gothic style as an expression of the Catholic faith itself, more than romanticism, contributed to the triumph of medieval architecture, which they began to actively study and preserve. It determined not only the construction of a large number of new churches in the "neo-Gothic style", but also the conservation and restoration of the ancients destroyed during the French Revolution and the Napoleonic Wars. It is no coincidence that the architect E.-E. Viollet-le-Duc, whose name marked a whole era in the restoration of historical monuments, considered the Gothic cathedral a symbol of the French nation ${ }^{17}$.

The beginning of the implementation of the "historical education program" F. Guizot can be considered the establishment on his initiative in October 1830 of the post of inspector general of historical monuments in the structure of the Ministry of Internal Affairs. The first general inspector of historical monuments was appointed politician, writer and archaeologist Louis Vite, who was in this post until 1834. Prosper Merimee, who replaced him, headed the general inspection of historical monuments from 1834 to 1860 . The functions that the general inspector should have performed formulated in a report by L. Vite at the end of his first official trip to the North of France in 1831: "To establish the existence and make a critical description of all the buildings of the kingdom, which either Athe, either by the nature of their architecture, or by the events of which they were witnesses, deserve the attention of an archaeologist, artist, historian, such is the first goal of the duties assigned to me. Secondly, I must take care of the preservation of these buildings, showing the government and local authorities ways to either prevent or stop their destruction" 18 .

${ }^{17}$ Bazen Zh. (1994) Istoriya istorii iskusstv: Ot Vazari do nashikh dney [History of Art History: From Vasari to the Present]. Moscow: Progress-Kul'tura. P. 217.

18 Nikolaeva N. S. (2008) Formirovanie gosudarstvennoy sistemy okhrany pamyatnikov vo vtoroy chetverti XIX veka (sravnitel'nyy analiz: Frantsiya i Rossiya) [Formation of the state system for the protection of monuments in the second quarter of the XIX century (comparative analysis: France and Russia)]. Izvestiya Rossiyskogo gosudarstvennogo pedagogicheskogo universiteta im A. I. Gertsena [Bulletin of the Russian State Pedagogical University named after A. I. Herzen]. № 80. P. 263. 
Naturally, one person was not able to complete these tasks. Therefore, when the post of inspector general was established, F. Guizot advocated the creation of local societies in the province by analogy with the Normandy Antiquarian Society, which, in his opinion, would most effectively preserve the monuments. In this connection, in French studies on the history of conservation activities, the formation of the Historical Monuments Service F. Guizot is seen as a response to the initiative of Count Arsis de Comon, who founded the Normandy Antiquarian Society in $1824^{19}$. F. Berse explains this reverence for F. Guizot with the vigor and fame of the founders of the Society, their significance in archaeological historiography. The activities of the Society of Antiquaries of Normandy, and directly of Arsis de Comon, played a significant role in organizing similar societies and conducting scientific meetings in the French provinces. In 1831, the Morini Antiquarian Society will be formed, in 1834 the West Antiquarian Society, and in 1836 the Picardy Antiquarian Society. Created in 1831, the Archaeological Society of the South of France will consider itself the successor to the Normandy Antiquarian Society. The idea of holding scientific meetings in France, successfully implemented by Arsis de Comon, was associated with a similar activity by Alexander Humbolt in Germany. The first scientific meeting was held in Caen in July 1833, the second in Poitiers in 1834. Two hundred people took part in their work. The result of such scientific meetings will be the creation in 1839 of the Provincial Institute ${ }^{20}$.

The success of Norman society led Arisis de Comon to the idea of creating a scientific society already on a national scale. In July 1834, he founded the French Archaeological Society, originally called the French Society for the Preservation and Description of Historical

${ }^{19}$ Bazen Zh. (1994) Istoriya istorii iskusstv: Ot Vazari do nashikh dney [History of Art History: From Vasari to the Present]. Moscow: Progress-Kul'tura. P. 94.

20 Nikolaeva N. S. (2008) Formirovanie gosudarstvennoy sistemy okhrany pamyatnikov vo vtoroy chetverti XIX veka (sravnitel'nyy analiz: Frantsiya i Rossiya) [Formation of the state system for the protection of monuments in the second quarter of the XIX century (comparative analysis: France and Russia)]. Izvestiya Rossiyskogo gosudarstvennogo pedagogicheskogo universiteta im A. I. Gertsena [Bulletin of the Russian State Pedagogical University named after A. I. Herzen]. № 80. P. 263. 
Monuments $^{21}$. The aim of the new Society was to study the monuments of France, compile their list and prevent their destruction or distortion by annoying restorations. Since its founding, the Society began annually conducting archaeological congresses in various provincial cities, reports on which were published in the "Bulletin monumental", and since 1845 they began to be issued as a separate publication. Thus, on the initiative of A. de Comon and with his direct participation in France, a powerful national network of scientific societies was formed.

A year earlier than the creation of the French Archaeological Society, the French History Society was formed, one of the founders of which was also F. Guizot, who was then Minister of Education. In January 1834, the charter of this Society was adopted, and work began on the study and publication of genuine sources related to national history. In July 1834, F. Guizot established the Committee of Historical and Scientific Works, the purpose of which was to study and publish unpublished documents on the history of France. In January 1835, another committee was created to facilitate the study and publication of unpublished documents on literature, philosophy, science and the arts relating to the general history of France - the Committee of Unpublished Monuments of Literature, Philosophy, Science and Art, considered in connection with the general history of France $^{22}$. This Committee united the main founders of the Service of Historical Monuments: V. Hugo, V. Cousin, L. Vite, O. Leprevo, S. Lenormann, P. Merimet, A. Lenoir, A.-N. Didrona. In 1837, the successor to F. Guizot, Minister of Education, Narsis-Achille de Salvandi, reorganized the Committee of Unpublished Monuments,

${ }^{21}$ Bazen Zh. (1994) Istoriya istorii iskusstv: Ot Vazari do nashikh dney [History of Art History: From Vasari to the Present]. Moscow: Progress-Kul'tura. P. 94.

22 Nikolaeva N. S. (2008) Formirovanie gosudarstvennoy sistemy okhrany pamyatnikov vo vtoroy chetverti XIX veka (sravnitel'nyy analiz: Frantsiya i Rossiya) [Formation of the state system for the protection of monuments in the second quarter of the XIX century (comparative analysis: France and Russia)]. Izvestiya Rossiyskogo gosudarstvennogo pedagogicheskogo universiteta im A. I. Gertsena [Bulletin of the Russian State Pedagogical University named after A. I. Herzen]. № 80. P. 263. 
dividing it into five sections in accordance with the five classes of the Institute of France. One of the sections was called the Committee of Arts and Monuments and was under the patronage of the Academy of Fine Arts. The tasks of this committee included the compilation of a list of monuments in France, concern for the preservation of destructible monuments, and assistance in organizing scientific work in the province ${ }^{23}$. At the time of the establishment of the Committee of Unpublished Monuments, F. Guizot appealed to scientific societies for cooperation, promising the provision of material assistance from the state, ensuring the exchange of publications and the annual publication of the most important scientific studies in a national journal ${ }^{24}$. In 1837 , the Commission of Historical Monuments was created in the structure of the Ministry of the Interior, whose functions also included identifying and studying monuments, compiling a list of them, ensuring their protection on the basis of subsidies specially allocated from the state, and directing restoration work ${ }^{25}$. Since its inception, the commission has relied on a previously formally established network of correspondents consisting of local scholars or scientific societies who were supposed to report on buildings in danger or on ongoing restorations. In twelve departments, these functions were performed by scientific societies. Where they were not, the prefects created commissions. Unfortunately, after ten years, the role of these

23 Nikolaeva N. S. (2008) Formirovanie gosudarstvennoy sistemy okhrany pamyatnikov vo vtoroy chetverti XIX veka (sravnitel'nyy analiz: Frantsiya i Rossiya) [Formation of the state system for the protection of monuments in the second quarter of the XIX century (comparative analysis: France and Russia)]. Izvestiya Rossiyskogo gosudarstvennogo pedagogicheskogo universiteta im A. I. Gertsena [Bulletin of the Russian State Pedagogical University named after A. I. Herzen]. № 80. P. 263.

24 Nikolaeva N. S. (2008) Formirovanie gosudarstvennoy sistemy okhrany pamyatnikov vo vtoroy chetverti XIX veka (sravnitel'nyy analiz: Frantsiya i Rossiya) [Formation of the state system for the protection of monuments in the second quarter of the XIX century (comparative analysis: France and Russia)]. Izvestiya Rossiyskogo gosudarstvennogo pedagogicheskogo universiteta im A. I. Gertsena [Bulletin of the Russian State Pedagogical University named after A. I. Herzen]. № 80. P. 264.

${ }^{25}$ Kuklinova I. A. (2001) Muzei Frantsii XIV - XIX vekov [Museums of France of the XIV - XIX centuries]. St. Petersburg: SPbGUKI. P. 76. 
provincial societies and correspondents was minimized ${ }^{26}$. In 1837 , following the tradition of the First Empire, a regular questionnaire was drawn up, consisting of 39 questions, according to which the prefects were to report on the most important monuments and monuments requiring urgent action to preserve them.

Based on their answers and with their help, the first monetary appropriations were determined. In 1840, the Commission of Historical Monuments published a list of monuments. Thus, with the establishment of the Commission of Historical Monuments, the formation of the state system for the protection of monuments, reflecting the intention of F. Guizot, aimed at inventorying all documents related to the spiritual and moral history of France, archives, libraries, monuments and works of art, was completed.

In this way the foundation was laid for an extensive classification system on which the French and later laws concerning monuments were built. A number of orders have established that the destruction or alteration of historical structures is permitted only with the permission of the Ministry of Education. However, due to the lack of legal authority, the measures taken by the government for the most part did not achieve their goal. Only the goodwill of the owners and the discretion of institutions independent of the Ministry of Education depended on the extent to which his orders were observed. Therefore, in 1875, the Minister of Education Henri-Alexander Vallon drafted a bill that concentrated all the care of the monuments in the hands of the Ministry of Education and supplied the Ministry with the necessary powers. Only on March 30, 1887, this project, after various upheavals and various alterations, was adopted by the Chamber of Deputies. And the export order contained in Section 18 of the Law was published on June 3, 1889. In general, the French law of March 30, 1897 owes its

26 Nikolaeva N. S. (2008) Formirovanie gosudarstvennoy sistemy okhrany pamyatnikov vo vtoroy chetverti XIX veka (sravnitel'nyy analiz: Frantsiya i Rossiya) [Formation of the state system for the protection of monuments in the second quarter of the XIX century (comparative analysis: France and Russia)]. Izvestiya Rossiyskogo gosudarstvennogo pedagogicheskogo universiteta im A. I. Gertsena [Bulletin of the Russian State Pedagogical University named after A. I. Herzen]. № 80. p. 264. 
occurrence mainly to representatives of art and science, as well as academic societies ${ }^{27}$.

The provisions of the first comprehensive law on March 30, 1887 were developed by the subsequent "Law on Historical Monuments" of December 31, 1913. An important innovation of this law was that it assumed a centralized record of not only state monuments, but also those cultural property that was privately owned. Also in this law, archaeological sites are characterized separately, although there are no special rules regarding archaeological excavations yet ${ }^{28}$.

\section{CONCLUSIONS}

The beginning of the process of forming a system of monument protection in France can be dated to the end of the 18th century - the adoption by the French revolutionary government of the decrees of the National Constituent Assembly, which nationalize all immovable and movable monuments, prohibit their destruction. The measures and actions of the government of this initial period are characterized by spontaneity, incompleteness of the plan, noble thoughts, not brought to implementation.

As the next stage, we can single out the creation of a single new center for the storage of ancient heritage in France at the Napoleon Bonaparte Museum. Collection of the collection was carried out by the right to seize military booty, was of a personal, subjective and extremely chaotic nature.

The restoration period is $1815-1830$ not made significant structural changes.

The direct formation of the state system for the protection of monuments in France was the result of the revolutions of 1789 and

27 Viland K. A. (1906) Okhrana pamyatnikov i rodiny v sovremennykh zakonodatel'stvakh [Protection of monuments and homeland in modern legislation]. Izvestiya Imperatorskoy Arkheologicheskoy Komissii [News of the Imperial Archaeological Commission]. № 20. Pp. 101-150.

28 Novyy frantsuzskiy zakon ob istoricheskikh pamyatnikakh (Utverzhden 31 dekabrya 1913 g.) (1916) [New French Law on Historic Monuments (Approved December 31, 1913)]. Izvestiya imperatorskoy arkheologicheskoy komissii [News of the imperial archaeological commission]. № 60. Pp. 106-116. 
1830. In the second quarter of the XIX century there was a rise in interest in national history, the national past, which was due not only to the natural development of science, but also mainly to political and socio-economic conditions. In France, the desire to restore national unity, the search for national consciousness was carried out on the basis of public policy. We can say that the government and state institutions in many ways not only initiated this activity, but also carried out leadership and control over its implementation. Special state institutions were created to collect, study and preserve monuments of national history, both written and tangible. The government of the country understood that it was impossible to solve the assigned tasks, the help of scientific societies, which began to develop actively at that time, was needed. In France already in the 1830s. a developed network of scientific societies involved in the study of ancient monuments has developed. It should also be noted the importance of the local administration, which contributed not only to the study of antiquities, but also to their preservation, finding sources of funding for these works. As a common problem, we can name the lack of local specialists, which greatly complicated the fulfillment of the tasks set, and above all, the creation of a set of monuments, which was considered as the main measure of their preservation.

The logical conclusion to the long process of forming the foundations of legislative protection of monuments was the adoption of the first comprehensive law on March 30, 1887, the provisions of which were subsequently developed by the "Law on Historical Monuments" of December 31, 1913.

\section{SUMMARY}

Interest in collecting in France arises in parallel with similar processes in other European countries and quickly, by the beginning of the 16th century, is becoming a noticeable phenomenon in the life of French society. Collecting collections turns into a phenomenon that covers literally all segments of the population. The idea of museums in France was formed throughout the eighteenth century, and the French Revolution was the impetus for the creation in France of the foundations of the legislative protection of monuments. The French 
revolutionary government by decree of the National Constituent Assembly of 1790 prohibited the destruction of immovable and movable monuments.

As the next stage, we can single out the creation of a single new center for the storage of ancient heritage in France at the Napoleon Bonaparte Museum. The Napoleon Museum was the last magnificent example of a collection of antiquities in the style of classicism. This museum is at the same time the crown and the end of the whole long revolutionary period in the history of France.

The direct formation of the state system for the protection of monuments in France was the result of the revolutions of 1789 and 1830. In the second quarter of the XIX century there was a rise in interest in national history, the national past, which was due not only to the natural development of science, but also mainly to political and socio-economic conditions. In France, the desire to restore national unity, the search for national consciousness was carried out on the basis of public policy. We can say that the government and state institutions in many ways not only initiated this activity, but also carried out leadership and control over its implementation. Special state institutions were created to collect, study and preserve monuments of national history, both written and tangible. The government of the country understood that it was impossible to solve the assigned tasks, the help of scientific societies, which began to develop actively at that time, was needed. In France already in the 1830s. a developed network of scientific societies involved in the study of ancient monuments has developed.

The completion of the long process of forming the legislative base was the adoption of the first comprehensive law on March 30, 1887, the provisions of which were subsequently developed by the "Law on Historical Monuments" of December 31, 1913.

\section{REFERENCES}

1. Kuklinova I. A. (2001) Muzei Frantsii XIV - XIX vekov [Museums of France of the XIV - XIX centuries]. St. Petersburg: SPbGUKI (in Russian) 
2. Dokumenty istorii Velikoy frantsuzskoy revolyutsii (1990) [Documents of the history of the Great French Revolution]. T. 1. Moscow: MGU, pp. 484-485.

3. David Zh.-L. (1933) Rechi i pis'ma zhivopistsa Lui Davida [Speeches and Letters by the Painter Louis David]. Moscow; Leningrad: Isogiz (in Russian)

4. Mikhaelis A. (1913) Khudozhestvenno-Arkheologicheskie otkrytiya za 100 let [Artistic and archaeological discoveries for 100 years]. Moscow: Izdanie Imperatorskogo Moskovskogo Arkheologicheskogo Instituta Imeni Imperatora Nikolaya II (in Russian)

5. Zhebelev S. A. (1923) Vvedenie v arkheologiyu. Chast' II. Teoriya i praktika arkheologicheskogo znaniya [Introduction to archeology. Part II. Theory and practice of archaeological knowledge]. Petrograd: Nauka i shkola. Pp. 80-81.

6. Kodeks Napoleona (1877) [Codex of Napoleon]. Sobranie grazhdanskikh zakonov guberniy Tsarstva Pol'skogo [Collection of Civil Laws of the Provinces of the Kingdom of Poland]. Pp. 159-164.

7. Malyshev O. O. (2015) Arkheologhichne pravo Franciji: gheneza ta suchasnyj stan [Archeological law of France: genesis and current state]. Chasopys Kyjivsjkogho universytetu prava [Journal of the Kyiv University of Law]. Pp. 33-37.

8. Malyshev O. O. (2018) Romansjka ta ghermansjka tradyciji arkheologhichnogho prava: sproba uzaghaljnennja [Romanesque and Germanic traditions of archaeological law: an attempt to generalize]. Pravova derzhava [Constitutional state]. № 29. Pp. 476-485.

9. Lebedev G. S. (1992) Istoriya otechestvennoy arkheologii [History of Russian Archeology]. St. Petersburg: SPbGU (in Russian)

10.Rytsarev K. V. (1995) Nekotorye tendentsii V zapadnoevropeyskoy arkhitekturnoy restavratsii XIX veka [Some trends in the West European architectural restoration of the XIX century]. Restavratsiya i arkhitekturnaya arkheologiya: Novye materialy i issledovaniya [Restoration and Architectural Archeology: New Materials and Research]. Moscow. № 2. Pp. 4-19.

11.Bazen Zh. (1994) Istoriya istorii iskusstv: Ot Vazari do nashikh dney [History of Art History: From Vasari to the Present]. Moscow: Progress-Kul'tura. (in Russian) 
12.Nikolaeva N. S. (2008) Formirovanie gosudarstvennoy sistemy okhrany pamyatnikov vo vtoroy chetverti XIX veka (sravnitel'nyy analiz: Frantsiya i Rossiya) [Formation of the state system for the protection of monuments in the second quarter of the XIX century (comparative analysis: France and Russia)]. Izvestiya Rossiyskogo gosudarstvennogo pedagogicheskogo universiteta im A. I. Gertsena [Bulletin of the Russian State Pedagogical University named after A. I. Herzen]. № 80. Pp. 261-270.

13.Viland K. A. (1906) Okhrana pamyatnikov i rodiny v sovremennykh zakonodatel'stvakh [Protection of monuments and homeland in modern legislation]. Izvestiya Imperatorskoy Arkheologicheskoy Komissii [News of the Imperial Archaeological Commission]. № 20. Pp. 101-150.

14.Novyy frantsuzskiy zakon ob istoricheskikh pamyatnikakh (Utverzhden 31 dekabrya 1913 g.) (1916) [New French Law on Historic Monuments (Approved December 31, 1913)]. Izvestiya imperatorskoy arkheologicheskoy komissii [News of the imperial archaeological commission]. № 60. Pp. 106-116.

\section{Information about the author: \\ Oleksii Prysiazhniuk,}

PhD (History), Associate Professor at the Department of World History and Methodology of Science, South Ukrainian National Pedagogical University named after K. D. Ushynsky 26, Staroportofrankovskaya str., Odessa, 65020, Ukraine ORCID ID: orcid.org/0000-0003-3727-5350 
NOTES 
Publishing house "Liha-Pres"

9 Kastelivka str., Lviv, 79012, Ukraine

44 Lubicka str., Toruń, 87-100, Poland

Printed by the publishing house "Liha-Pres"

Passed for printing: November 25, 2019. A run of 150 copies. 